\title{
Inhibition of EGFR Suppresses Ethyl Alcohol and Tobacco Cell Effects on Growth of Human Oral Keratinocytes and Human Papillomavirus 16 Entry as a Function of Furin
}

\author{
Joel L. Schwartz¹, Alexander Munaretto², Sirlata Bagchi' ${ }^{3}$, David Crowe³, Gonzalo Izaguirre ${ }^{3}$ \\ ${ }^{1}$ Department of Oral Medicine and Diagnostics, University of Illinois at Chicago, Chicago, USA \\ ${ }^{2}$ College of Dentistry, University of Illinois at Chicago, Chicago, USA \\ ${ }^{3}$ Department of Periodontics, University of Illinois at Chicago, Chicago, USA \\ Email: joschwar@uic.edu, amunaretto7@gmail.com, sbagchi@uic.edu, dcrowe@uic.edu, goniza@uic.edu
}

Received 1 January 2015; accepted 16 January 2015; published 21 January 2015

Academic Editor: Sibu P. Saha, University of Kentucky, USA

Copyright $@ 2015$ by authors and Scientific Research Publishing Inc.

This work is licensed under the Creative Commons Attribution International License (CC BY).

http://creativecommons.org/licenses/by/4.0/

(c) $\underset{\mathrm{EY}}{\mathrm{F}}$ Open Access

\section{Abstract}

Background: Reported are increased risks for malignant transformation in human oral keratinocytes (HOK) from ethyl alcohol (ETOH), tobacco products or human papilloma virus oncogenic subtype 16 (HPV 16) infections. We examined various HOK cell responses to these factors to show inhibitors of epidermal growth factor receptor (EGFR) also inhibits furin; proprotein convertase (FC) and HPV 16 entry in HOK. Methods: Immortalized HOK by HPV 16 (HPV 16B) or human telomerase (hTERT); primary foreskin keratinocytes (NHFK), primary HOK, buccal keratinocytes (NHBK) and oral SCC-25 were treated with dibenz[a,I]pyrene (DBP), anthraquinone; nitrosamine (NNAL) or ethyl alcohol (ETOH) and acetaldehyde (AA). ETOH was tested for synthesis of malondialdehyde (MDA) and alcohol dehydrogenase expression (ADH). ETOH, and PAH were evaluated by Western immunoblot for oncogene changes, and phosphorylated EGFR expression. Inhibition of EGFR by WZ4002 and Erlotinib and/or carcinogens effect on HPV 16 entry were studied. A green fluorescent pseudovirus (PsV); chloromethylketone (CMK) an inhibitor of furin activity and Western immunoblot of furin cell distribution further characterized HPV 16 entry. Results: ETOH (10 $\mu$ M) increased expression of phosphorylated EGFR and HPV 16 entry through furin activity, and membrane, nuclear and cytoskeletal accumulations. CMK suppressed HPV 16 entry and blockage of ADH while aldehyde dehydrogenase (ALDH) enhanced HPV 16 entry. Similarly PAH, DBP (4 - 8 nM), anthraquinone ( $98 \mathrm{nM})$ and NNAL $(6.9 \mu \mathrm{M})$ enhanced HPV 16 entry through furin activity and mem- 
brane, nuclear and cytoskeletal accumulations. Furthermore, WZ4002 and Erlotinib suppressed expressions of phosphorylated EGFR, FC activity, and HPV 16 entry. ETOH and DBP treatments also enhanced expressions of protease activated receptor-1 (PAR-1), and p21 waf1 while depressed p16 and p27 KIP1 expressions in HOK/HPV 16B cells. Conclusion: EGFR inhibitors are candidates for suppression of alcohol and tobacco effects on EGFR phosphorylated expression; keratinocyte growth, and HPV 16 entry and prevention treatment for HPV related diseases.

\section{Keywords}

Ethyl Alcohol, Tobacco, Poly-Cyclic Aromatic Hydrocarbons, Nitrosamines, DNA Damage, Tumor Suppressor, Oncogene, HPV 16, Furin, Proprotein Convertase, EGFR Inhibitors, Phospho-L-Tyrosine Inhibitors

\section{Introduction}

Malignant transformation of oral keratinocytes is associated with enhanced expression of phosphorylated epidermal growth factor (EGFR) [1]-[5]. This occurs through tyrosine kinase activity which regulates epithelial cell growth, especially squamous cell carcinomas [6]-[8]. Furthermore, EGFR phospho-tyrosine inhibitors are now routinely used to treat or enhance survival of patients with late stage oral squamous cell carcinoma (OSCC) [8]. It is also recognized that the architecture of the oral mucosa which contains a stratum basilis is the proliferativestem cell compartment and has a very high level of EGFR expression [1] [2] [9]. The ligand epidermal growth factor (EGF) binds to EGFR and this receptor is associated with other members Erb: Erb1, Erb2, Erb3, Erb4 [9]-[11]. There are also additional ligands: transforming growth factor-alpha (TGF- $\alpha$ ); amphiregulin; betacellulin; epiregulin, epigen, neuregulins (NRG): NRG-1, NRG-2, NRG-3, and heparin-binding EGF like growth factor (HB-EGF) [10] [11]. It is further stated by Konda et al., that TGF- $\alpha$; EGF and HB-EGF share the EGFR receptor [12].

HB-EGF is particularly interesting because of its possible function as a heparanase and influence upon heparan sulfate binding proteins such as proteoglycans which include the synedcans 1,4 or S100A8/S100A9 complexes [10] [13]. This latter heterocomplex, we have identified as associated with 1) enhanced phosphor-L-trosine EGFR expression; 2) inhibits kinases: casein kinase I and II; 3) promotes NADPH oxidase expression; 4) acts as a cytoplasmic calcium sensor; 5) enhances reactive oxygen substances (ROS) to alter EGFR activity, and 6) effects differentiation and adhesion for squamous cell carcinomas. These cell surface molecules are therefore identifiable with malignant epithelial behaviors such as enhanced migration [14]-[18].

Another less recognized association for EGFR is regulation of FC [19]-[21]. FC is reported to effect cell growth of mucous epithelial cells through differentiation activity of EGFR and an increased TGF- $\alpha$ expression. In addition, this is accompanied by a reduction in FC to depress migration and malignant keratinocyte behavior [22]-[24]. It is also noted that EGFR contains a furin like sequence and EGFR is responsive to both HB-EGF and FC [25] [26].

Stated above there are a variety of ligands for EGFR, however, there are seven different growth factors with a central functional structure designated as the "EGF module" [21]. This module sequence is furin like because it contains six conserved cysteines responsible for binding to the EGFR. In addition, transactivation of EGFR is mediated by cleavage of membrane-anchored pre-forms of ligands to produce "ectodomain shedding" [20]. Sheddases are exemplified by disintegrin and metalloproteases (ADAMs) [11] [19] [20] [27]. These types of enzymes are of importance to epithelial cell types such as oral keratinocytes because of their relationship to cell to cell adhesion properties. Membrane-anchored peptides can be biologically activated by proximal signaling, or soluble growth factor ligands; such as soluble forms of furin which may act in an endocrine, paracrine, or autocrine manner [10] [11] [19] [28]. It is also reported that the catalytic active metalloproteases, with a ADAM domain is expected to function as an intramolecular chaperone. However, this activity is dependent on furin accumulation at the golgi. This is consistent with the notion that FC cycles from the membrane to the cytosol and cytoskeleton to the nuclear membrane and back again [11] [20]. Furin is a member of a nine-member protein convertase (PC) family: furin; PC1/3; PC2; PC4, PC5/6; PC7; SKI-1/SIP and PCSK9 [23] [24]. Therefore furin is reported to be a mediator of epithelial cell malignant motility and is described as a "master switch" for regula- 
tion of malignant behavior [24].

Furin activity mediates human papilloma virus 16 (HPV 16) entries which are reported to predominate in an epithelial cell coated with surface heparan sulfate proteoglycan [13]. Furin cleaves HPV L2 virion protein, which is required for infection while L1 is also present as a major capsid protein to assist in self-assembly of icosahedral virus-like particles [29]-[31].

Furin is only one of the eight known cofactors for HPV 16 entry into epithelial cells which characterizes selective HPV mucotropism. These include: 1) clathrin coated vesicles; 2) endocytic mechanism; 3) transport protein particle subunit 8 ; 4) a negative charge on entry membrane; 5) annexin A2; 6) integrins $\alpha_{6} \beta_{14}$; 7) cyclophillin B; 8) tetraspanins and growth factor receptors, such as EGFR [32]-[37].

In their review, Truong and Carroll provided evidence for redox regulation of EGFR functional expression [38]. Exogenous cell damage chemicals such as, ETOH or tobacco derived derivatives are expected to alter this redox regulation of EGFR through enhanced numbers of oxidative effects. Oxidative damage to nuclear bases to create defects particularly at cytosine phosphorylated guanine islands; larger nucleotide mutations, and epigenetic defects (e.g., methylation, acetylation, phosphorylation) also occur [39]-[43]. Secondly oxidative damage to cell membrane structures such as EGFR is anticipated.

These damages lead to nuclear instability and poorly regulated keratinocyte growth. Redox changes will also affect the balance between kinases and phosphatases and ultimately phosphorylation of EGFR. Moreover, sensitive polyphenol oxidases are affected. These are tyrosinases that convert tyrosine to o-quinones and reduce the availability of tyrosine and phospho-L-tyrosine kinase concentration [44].

In addition, quinones can have a poly-cyclic aromatic hydrocarbon origin derived from oxidation of pro-carcinogenic ROS from tobacco and ETOH products. These chemicals will also contribute to an enhanced ROS environment to produce a quinone synthesis prone environment [45].

Recently we shown that ETOH metabolism from oral commensal Streptococcus spp. or from HOK increases levels of ROS and HOK synthesize heparan sulfate binding, syndecans $(1,4)$ proteins. These proteins mediate adhesion but are degraded by heparanase. In parallel we noted a reduction in phospho-L-tyrosine EGFR expression and HPV 16 entry [13].

One particular ROS derived from ETOH metabolism is AA, which is a carcinogen and associated with an increased risk for epithelial malignant transformation leading to oral squamous cell carcinoma (OSCC) [13]. AA also is synthesized with tobacco (e.g., smoke and E-cigarette) products [46]. AA is found in association with premalignant and malignant lesions and induces a DNA bulky adduct in parallel with reduced DNA repair, exemplified by $\mathrm{O}^{6}$-methylguanidine transferase [40] [41]. AA also fosters increased permeability through epithelial membrane and DNA damage by formation of bulky adducts $\mathrm{N}^{2}$-acetaldehyde deoxyguanine. Furthermore, AA: 1) modifies binding of proteins (e.g., microtubules, actin polymerization); 2) suppresses or modifies enzyme activities (e.g., convertases) and 3) binds with $\mathrm{GSH}_{\text {red }}$ to produce a disruption of cellular oxidative state, with lipid peroxidation and formation of hydroxyl radicals [47] [48].

This study explores the ROS effects of ETOH, tobacco derived carcinogens, on HOK cells: normal; immortalized, and malignant cell types with emphasis on oncogene expression, phosphorylation of EGFR and EGFR inhibition. We record a novel relationship between EGFR inhibition and furin convertase activity that results in a significant reduction in HPV 16 entry. This finding may enhance clinical prevention/early inhibition by EGFR inhibitors for a reduction in HPV related carcinomas or dermatologic conditions such as condylomas and oral focal epithelial hyperplasia (Heck's disease).

\section{Methods and Materials}

\subsection{Chemicals}

Acetaldehyde (1.1 $\mu \mathrm{M} ; 10 \mu \mathrm{M}$ stock) (Sigma-Aldrich). Ethyl Alcohol (200 proof) (5.0\%, v/v; $10 \mu \mathrm{M} ; 1 \%$, v/v; 2 $\mu \mathrm{M} ; 0.5 \%, \mathrm{v} / \mathrm{v} ; 1 \mu \mathrm{M})$ (Sigma-Aldrich, St. Louis.MO). Decnoyl-Arg-Val-Lys-Arg-Chloro-methyl-ketone (CMK) (Bachem, ENZO, Life Sciences. Farmingdale, NY; stock: $100 \mu \mathrm{M}$, working concentration $1.0 \mu \mathrm{M}$ ) is an irreversible cell permeable competitive inhibitor of proprotein convertases: furin /SpC1; SPC2/PC2; SPC4/ PACE4; SPC6/PC5/PC6 and SPC7/LPC/PC7/PCB; dimethylsulfoxide (DMSO) (Sigma-Aldrich Chemical, St. Louis, MO) $(0.1 \mu \mathrm{M})$. 4-Methylpyrazole hydrochloride (4Mpyr) (1.0 mM stock; working concentration: 0.05 - 0.025 $\mathrm{mM}$ ) (Sigma-Aldrich) an inhibitor of alcohol dehydrogenase (ADH). Tetraethylthiuram disulfide (TDS) (Disulfiram; $0.5 \%$ stock; working concentrations: $0.25 \%(660 \mu \mathrm{M}-0.12 \%(330 \mu \mathrm{M})-0.012 \%(12 \mu \mathrm{g} / \mathrm{mL}$.; $33 \mu \mathrm{M})$ is an 
inhibitor of acetaldehyde dehydrogenase and proteosome inhibitor. Dibenz(a,l)pyrene (DBP) (stock at $680 \mu \mathrm{M}$ dissolved in methylene chloride, working concentration 4.3 $\mu \mathrm{M}$ dissolved in DMSO : 17.0 - $8.0 \mathrm{nM}$; SUPELCO, Bellefonte, PA). (-)-Nicotine solution (3-(1-Methyl-2-pyrrolinyl)pyridine) stock $1.0 \mathrm{mg} / \mathrm{ml}$ in methanol, 62.5 $\mathrm{nM}(10.1 \mu \mathrm{g} / \mathrm{mL})$ (Sigma-Aldrich Chemical, St. Louis, MO); 4-(Methylnitrosoamino)-1-(3-pyridinyl)-1-butanone (NNK; $44.7 \mathrm{nM}(9.2 \mu \mathrm{g} / \mathrm{mL})$ ); 4-(Methylnitrosamino)-1-(3-pyridyl)-1-butanol (NNAL; $84.7 \mathrm{nM}$ (7.7 $\mu \mathrm{g} / \mathrm{mL}$ ) (Sigma-Aldrich Chemical, St. Louis, MO). Epidermal growth factor (EGF); Sigma Chemical, St. Louis $\mathrm{MO}$ and used at a working concentration of $4 \mu \mathrm{g} / \mathrm{ml}$. Erlotinib hydrochloride (Tarceva; N-(3-ethynylphenyl)6,7-bis(2-methoxy ethoxy quinazolin-4-amine)(250 mg, $6.3 \mu \mathrm{M}$ stock; Cayman Chemical, Ann Arbor, MI)WZ4002 (N-(3-(5-chloro-2-(2-methoxy-4-(4-methylpiperazin-1-yl)phenylamino)pyrimidin-4-yloxy)phenyl) acrylamide) (0.20 $\mu \mathrm{M}$ stock; Selleckchem.com, Houston TX).

\subsection{Cells}

HOK/HPV 16B, and human telomerase immortalized (hTERT) human oral keratinocytes (HOK) were used [13]. Growth medium: Dulbecco's Modified Eagle’s Medium (DMEM) +/- Enhanced GLU (GIBCO, Life Technologies, Grand Island, NY) with the dipeptide L-alanyl-L-glutamine (GIBCO, Life technologies, Grand Island, NY) supplemented with 10\% fetal bovine serum (Sigma-Aldrich, St. Louis MO.) and 10,000 units/ml. of streptomycin and penicillin for 293TT human embryonic kidney cells [13]. Primary cells normal human buccal keratinocytes (NHBK) and normal neonatal human foreskin-epidermal keratinocytes (NHFK) (Lonza, Clonetics, Allendale, NJ) were grown in keratinocyte growth medium with supplements (Lonza).

\subsection{Cell Nuclear and Proliferation Status}

Antibody to H2AX (anti-gamma H2A.X (phosphor S139) identified using polyclonal (AbCam, Cambridge MA) (1:200 dilution) and monoclonal 5-bromo-2'-deoxy uridine (BrdU) (Sigma Chemical, St. Louis, MO) at (1:500) were used to identify these proteins.

\subsection{Trypan Blue Dye Exclusion}

1:20 dilution of trypan blue (0.25\%) (Sigma-Aldrich Chemical, St Louis, MO) is used to test viability of cells. A calibrated micrometer using a Leica inverted microscope (W. Nuhsbaum Inc., McHenry, IL) is used to assess this number at X10.

\subsection{Bromodeoxyuridine Incorporation and Proliferation Assay}

5-Bromo-2'-deoxyuridine (BrdU) is a thymidine analog that competes with thymidine for incorporation into DNA during S-phase of the cell cycle. HOK/HPV 16 B cells were grown until 50\% confluent on 4 chamber glass slide chambers (NUNC ${ }^{\mathrm{TM}}$, Lab-Tek ${ }^{\mathrm{TM}}$ II CC2; Fisher-Thermo Scientific). BrdU is added (1:1000) and cells are incubated for $24 \mathrm{~h}$ at $37^{\circ} \mathrm{C}, 5 \% \mathrm{CO}_{2}$. Cells are washed gently in DMEM + Ham F12 without serum at least three times. Added anti-BrdU antibody immediately prior to addition made dilution (1:10). Cells are incubated for $1 \mathrm{~h}$ with mouse monoclonal $\left(1.5 \mathrm{mg} / \mathrm{mL}\right.$, clone BU-33) antibody at $37^{\circ} \mathrm{C}$ and a secondary fluorescent isothiocynate conjugated (FITC) antibody to mouse (Sigma-Aldrich Chemical, St. Louis MO) 30 minutes at $37^{\circ} \mathrm{C}$. After incubation cells are again washed and fixed for 30 seconds in $1 \%$ paraformaldehyde. Furthermore, VECTASHIELD (Vector, Burlingame, CA) mounting media is used for cover slipping before viewing in a Leica inverted photomicroscope. Number of positive fluorescent cells is immediately counted in at least three areas of each chamber at $40 \times$ after removing chamber walls.

\subsection{Micronucleus Assay}

To assess micronucleus presence we initially stain the cells with the vital nuclear stain Hoechst $33342(1 \mu \mathrm{g} / \mathrm{mL})$ (Sigma Chemical, St Louis, MO). DNA and chromatin is detected with this dye. After fixation using 1\% paraformaldehyde for $2-3$ at $4^{\circ} \mathrm{C}$ and gently rinsing of human oral keratinocytes with phosphate buffered saline (1X) (PBS) a standard solution of Mayer's hematoxylin (Certified hematoxylin (1.0 g/l), sodium iodate $(0.2 \mathrm{~g} / \mathrm{l})$, aluminum ammonium sulfate $12 \mathrm{H}_{2} \mathrm{O}(50 \mathrm{~g} / \mathrm{l})$, chloral hydrate (50 g/l) and citric acid (1 g/l) (Sigma-Aldrich Chemical, St. Louis, MO) is used to visualize chromosomes after 1 minute and rinsing in PBS. Micronuclei are assessed: a) size of micronuclei: 1/16th and 1/3rd of the mean diameter of the main nuclei; b) non-retractile; c) not 
linked or connected to the main; d) touch but not overlap the main nuclei, and e) usually have the same staining intensity as the main nuclei. We count at least $3-400$ cells in three $\times 40$ areas [49].

\subsection{Malonialdehyde Assay (Thiobarbituric Acid Reactive Substances (TBARS)}

Malonialdehyde (MDA) produces a TBA adduct that is measured shortly after formation following exposure to ETOH or AA in HOK cells which are lysed using a Sodium dodecyl sulfate buffer (pH 8). MDA is assessed using an optical density (OD) at $525 \mathrm{~nm}$. (Cell BioLabs Inc., San Diego CA).

\subsection{Viability of Keratinocytes Exposed to ETOH or Acetaldehyde (AA)}

Keratinocytes viability was assessed as previously described. Keratinocytes were directly exposed to ethyl alcohol (ETOH) (5.0\%, v/v; $10 \mathrm{mg} / \mathrm{mL} ; 10.75 \mu \mathrm{M})$, and acetaldehyde (AA: $10 \mu \mathrm{M})$ (Megazyme,UK) [13] [50].

\subsection{DNA Content and Cell Cycle Analysis}

Cells were plated on to tissue culture chamber plastic slides (Nunc, Lab-Tek, Sigma-Aldrich, St. Louis, MO) and grown to $40 \%$ - 50\% confluence. Hoechst 33342 stains $(10 \mathrm{mg} / \mathrm{mL}$ in $\mathrm{H} 2 \mathrm{O}$ stock solution at a 1:100 dilution $(1 \mathrm{mg} / \mathrm{ml})$ nuclei and excess stain is removed by a wash in PBS and Hoechst 33,342 stain is measured at $\lambda$ ex$353 \mathrm{~nm}, \lambda \mathrm{em}-483 \mathrm{~nm}$ using a laser scanning cytometer, iCyte. (Compucyte, Cambridge, MA) with iCys software algorithm was transferred to MODFIT 4.0 (Verity, Topsham, ME).

\subsection{Production of Human Papilloma Virus Pseudovirus (PsV)}

293TT cells are an adenovirus transformed cell line with a stably integrated $\mathrm{SV}_{40}$ genome with high levels of large $\mathrm{T}$ antigen. PsV production and an Optiprep purification method using overnight incubation of crude cell lysate at $37^{\circ} \mathrm{C}$ (Buck CB Curr Protocol.2007) is available at

http://home.ccr.cancer.gov/lco /pseudovirusproduction.htm. A map of HPV 16 PsV packaging plasmid (p16sheLL for HPV and pCDNA-GFP for GFP gene) driven by the cytomegalovirus (CMV) promoter is also found at this website [51]. Our system relies upon co-propagation of L1/L2 expression plasmid together with a reporter plasmid (green fluorescent protein (GFP)) to generate high titer of mature PsV stocks for visualization.

\subsection{Pseudovirus (PsV) Infection}

Pseudoviral like particles (PsV) were added into 6-well plates coated with collagen (Type IV) containing 293TT or hTERT HOK cells at a $50 \%-60 \%$ confluence $\left(5 \times 10^{5}\right.$ cells). Addition of PsV (50 $\mu \mathrm{L}$ of a 1:1000 crude cell lysates dilutions) occurred after inhibitors and/or chemicals were added during a $24 \mathrm{~h}$ incubation and washing with medium. Entry was monitored at least 7 days for GFP expression as a consequence of plasmid replication for hTERT HOK cells. Before addition of PsV for experimental studies we conducted a titration assay (200-10050-25-10-5 microliters) for each cell line to determine maximum expression of GFP through a week. PsV produced from pSheLL16 are not oncogenic viable HPV 16 virions because they lack transformation potential and cannot be transferred between individuals [52] [53].

\subsection{Quantitation of PsV Entry Assay}

HPV 16 entry (PsV) assessment was accomplished using two different approaches. 1) Count the number of fluorescent epithelial cells in dark field in a well using at least 3 photomicrographs $(40 \times)$. The total number of cells in the treatment well is counted using a bright field photomicrograph image (40×). 2) Epithelial cells are plated into a 96 well tissue culture plate. After HPV 16 PsV entry fluorescent detection is accomplished using a fluorometer using green filter (excitation max (nm) 395; emission max (nm) 509; excitation filter 400/30\#360/40; emission filter 508/20) (BioTek FLx800 Fluorescence Microplate Reader, Winooski, VT). Fluorescent unit values are obtained dividing experimental—control untreated background values raw numbers are obtained from fluorometer [52] [53].

\subsection{Cell Fractionation}

We used a commercial kit (compartment protein extraction kit) purchased from BioVision, Mountain View, CA. 
The kit provides sequential isolation of cytoplasmic, nuclear, membrane, and cytoskeleton proteins from HOK/ HPV 16B cells (catalog \# K270-50).

\subsection{Western Immunoblot Detection}

Mouse monoclonal to AD1A; alcohol dehydrogenase (Novus Biologicals, Littleton, CO) (1:200), anti-phosphotyrosine epidermal growth factor antibody (Abcam rabbit monoclonal, ab40815 (1:400 (0.4 $\mu \mathrm{g} / \mathrm{ml}$.) and antifurin antibody (Abcam rabbit polyclonal 28,547 reacts with amino-terminal end) used at 1:200 for cell immunohistochemistry and western immunoblot. Rabbit anti-retinoblastoma is a $\mathrm{G}_{1}$ detector (1:100); rabbit antibody for c-myc which is a proto-oncogene associated with tumors; rabbit anti-p53, is a cell cycle regulator; interacts with p21 waf1 to regulate cell cycle directly with cyclin dependent kinases. The antibody epitope resides between amino acids 46-55 (1:500); mouse monoclonal anti-p21 ${ }^{\text {waf1 }}$ recognizes the epitope in the N-terminal amino acids 17 - 30 within the cyclin-kinase (CDK) binding domain of the p21 ${ }^{\text {WAF1/Cip1 }}$ (1:500) (Sigma-Aldrich Chemical, St. Louis, MO). Rabbit polyclonal anti-p16 $6^{\mathrm{INK}}$ (1:500) (Sigma-Aldrich Chemical, St. Louis, MO); rabbit polyclonal anti-p27 $7^{\text {Kip1 }}$ (1:100; (Santa Cruz, San Diego, CA), Monoclonal antibody to $34 \mathrm{kDa}$ protein identified as p34 or cyclin-dependent kinase 4 (cdk4) which regulates $\mathrm{G}_{1}$. This antibody is produced in mouse clone DCS-31 and ascites fluid (Sigma-Aldrich Chemical, St. Louis, MO); syndecan-4 H-140 (rabbit, polyclonal) (Santa Cruz, CA) and monoclonal antibody, clone 6A7H10 in ascites fluid (1:500) protease activated receptor, 1 (PAR1) (AbCam, Cambridge, MA) Dilutions used for immunodetection were between 1:50 to 1:400 and detection used chemiluminescence (ECL, Amersham, and Piscataway, NJ).

\subsection{Proprotein Convertase Assay}

Using 293TT or hTERT HOK cells activity of proprotein convertase was assessed following lysate of cells and use of Boc, t-butoxycarbonyl; AMC, 7-amino-4-methyl coumarin as substrate in the form of BOC-Arg-Val-ArgArg-AMC acetate salt $(100 \mu \mathrm{M})$ and fluorescent detector of activity as identified in a fluorimeter at excitation $\lambda$ $=380 \mathrm{~nm}$; emission $\lambda=460 \mathrm{~nm}$. The buffer used was composed of $200 \mu \mathrm{M}$ substrate; $200 \mathrm{mM}$ 4-(2-hydroxyethyl)-1-piperazineethanesulfonic acid (Hepes) pH 7.6; $2 \mathrm{mM}$ copper chloride, and $2 \mathrm{mM}$ mercaptoenthanol (50 $\mu \mathrm{l})$. Equal amounts of buffer and substrate is added to supernatant or cell lysis, Controls included lysate without substrate added, solvent (DMSO) vehicle for tobacco derived carcinogens. Results were taken at intervals of 10 to 240 minutes over 3 days. Values were obtained after subtraction of control-experimental fluorimeter results.

\subsection{Statistical Analysis}

A paired dependent two tailed Student's t test with a confidence limit of $\mathrm{p} \leq 0.01$ determined level of significance between two comparative groups. Results presented in the figures are a product of triplicate or quadruplicate mean counts from chambers or wells and this resulted in fractions of whole numbers which were rounded to the nearest whole number to reflect the practical situation.

\section{Results}

Dermatologic and physiologic change as a result of sporadic, intermittent, or daily environmental exposures for human oral keratinocytes (HOK) requires further study of events that regulate human papillomavirus (HPV) infection susceptibility. To study this relationship we used laboratory assays with incubation with ethyl alcohol (ETOH); acetaldehyde (AA), and tobacco product derived carcinogens (PAHs: DBP; B[a]P, anthraquinone, NNK, NNAL).

\subsection{DNA Content and Cell Cycle Effects from ETOH/AA on HOK/HPV 16B Cells}

Initially we noted that ETOH (5\%, v/v; $10 \mu \mathrm{M})$; AA $(1.0 \mu \mathrm{M})$ or ETOH+ AA incubation with HPV/HPV 16B cells (viability $>92 \%$, trypan blue, Hoechst 33342 , $>94 \%$ ) caused a shift in DNA content to more cells with polyploidy ( $>2 \mathrm{~N}$ ) as signified by a selective shift to the right or left dependent on treatment (Figure 1(a)). For example, ETOH treatment resulted in a right shift ploidy change during $G_{2}+$ M. In contrast AA treatment enhanced ploidy during $G_{1}$. This estimation was validated through a cell cycle analysis that showed untreated HOK/HPV 16B cells have more cells in S phase compared to the other phases of the cell cycle (Figure 1(b) and Table 1). 

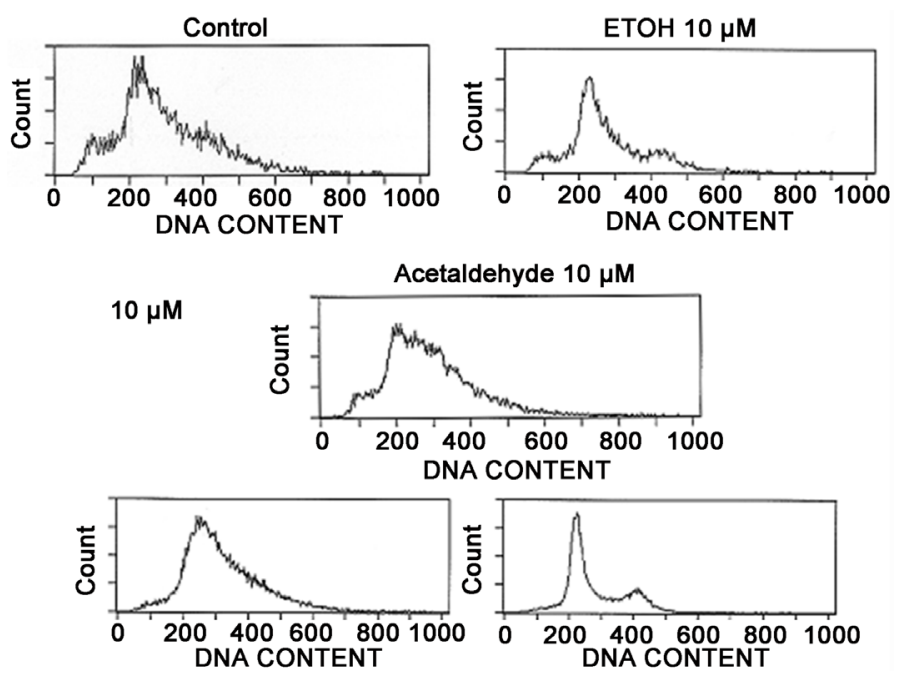

(a)
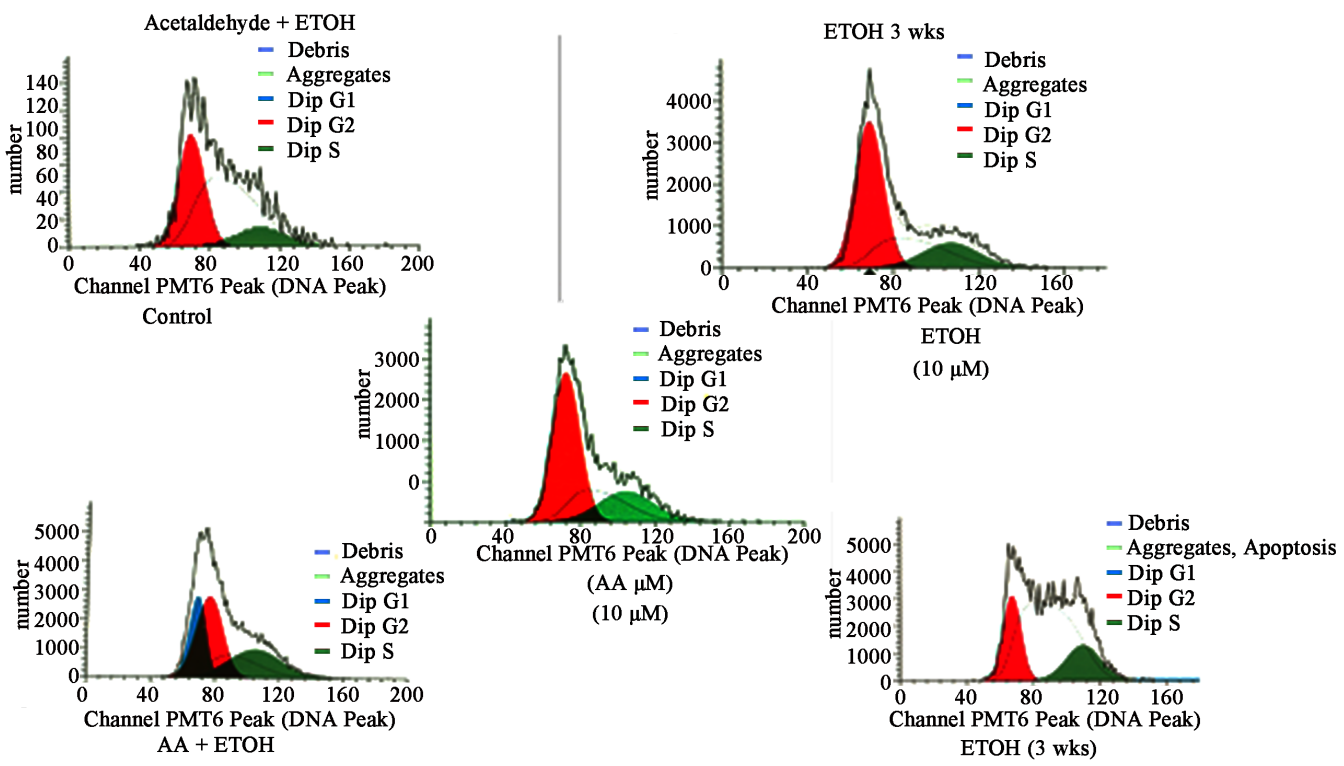

(b)

Figure 1. DNA Content and Cell Cycle Effects from ETOH/AA on HOK/HPV 16B Cells. (a) Examination of DNA content for HOK/HPV 16B cells following exposure to ETOH (10 $\mu \mathrm{M})$, AA $(10 \mu \mathrm{M})$, or $\mathrm{ETOH}$ and Acetaldehyde (AA). Time of incubation was $24 \mathrm{~h}$ or 3 weeks. A shift to the right indicated an increase in ploidy; (b) Cell cycle analysis indicated that ETOH or AA increase numbers of cells in $\mathrm{G}_{2}+\mathrm{M}$. This result was further accentuated with time (3 weeks).

\section{Table 1. Cell cycle effect from ETOH and AA treatments.}

\begin{tabular}{cccc}
\hline Groups & $\mathrm{G}_{1}$ & $\mathrm{~S}$ & $\mathrm{G}_{2}+\mathrm{M}$ \\
\hline Untreated HOK/HPV 16B & $36.09 \%+/-15.1 \%$ & $51.88 \%+/-12.3 \%$ & $12.04 \%+/-13.0 \%$ \\
ETOH $(10 \mu \mathrm{M})$ & $24.63 \%+/-7.4 \%$ & $27.01 \%+/-10.2 \%$ & $54.63 \%+/-8.8 \%$ \\
AA $(1 \mu \mathrm{M})$ & $54.40 \%+/-6.0 \%$ & $23.75 \%+/-9.2 \%$ & $21.85 \%+/-8.0 \%$ \\
AA $(1 \mu \mathrm{M})+\mathrm{ETOH}(10 \mu \mathrm{M})$ & $45.43 \%+/-5.4 \%$ & $23.20 \%+/-3.0 \%$ & $31.37 \%+/-5.6 \%$ \\
ETOH $(3$ wks $)(10 \mu \mathrm{M})$ & $30.09 \%+/-4.0 \%$ & $8.63 \%+/-9.9 \%$ & $61.28 \%+/-7.4 \%$ \\
\hline
\end{tabular}


In contrast we note changes from these values for only ETOH treatment which showed increases in checkpoints $G_{1}$ and $G_{2}+M$ compared to S phase (Figure 1(b) and Table 1). In comparison only AA treatment indicated a higher percentage of cells in $\mathrm{G}_{1}$ (Figure 1 (b) and Table 1 ). This pattern was accentuated by combination of AA and ETOH (Figure 1(b) and Table 1). An additional longer incubation for ETOH after 3 weeks also showed the previous ETOH pattern and further accentuated from untreated values (Figure 1(b) and Table 1 ( $p<0.0001$ ). These results further indicated a possible growth factor induction that accelerated the cell cycle pushing HPV/HOK $16 \mathrm{~B}$ cells toward mitosis. This point will be reinforced with additional assays described below.

\subsection{HOK and Other Epithelial Cells Response to ETOH}

In Figure 2, four addition assays were conducted to assess additional cell biologic effects from ETOH exposures. These included:

A) Level of AA in conjunction with \% number of HOK/HPV 16B cells that express alcohol dehydrogenase (ADH). This assay characterizes the metabolism of ETOH of HOK/HPV16 cells for $1 \mathrm{~h}$ and $24 \mathrm{~h}$. These periods of exposure compared to control enhanced both AA concentration in medium and ADH expression.

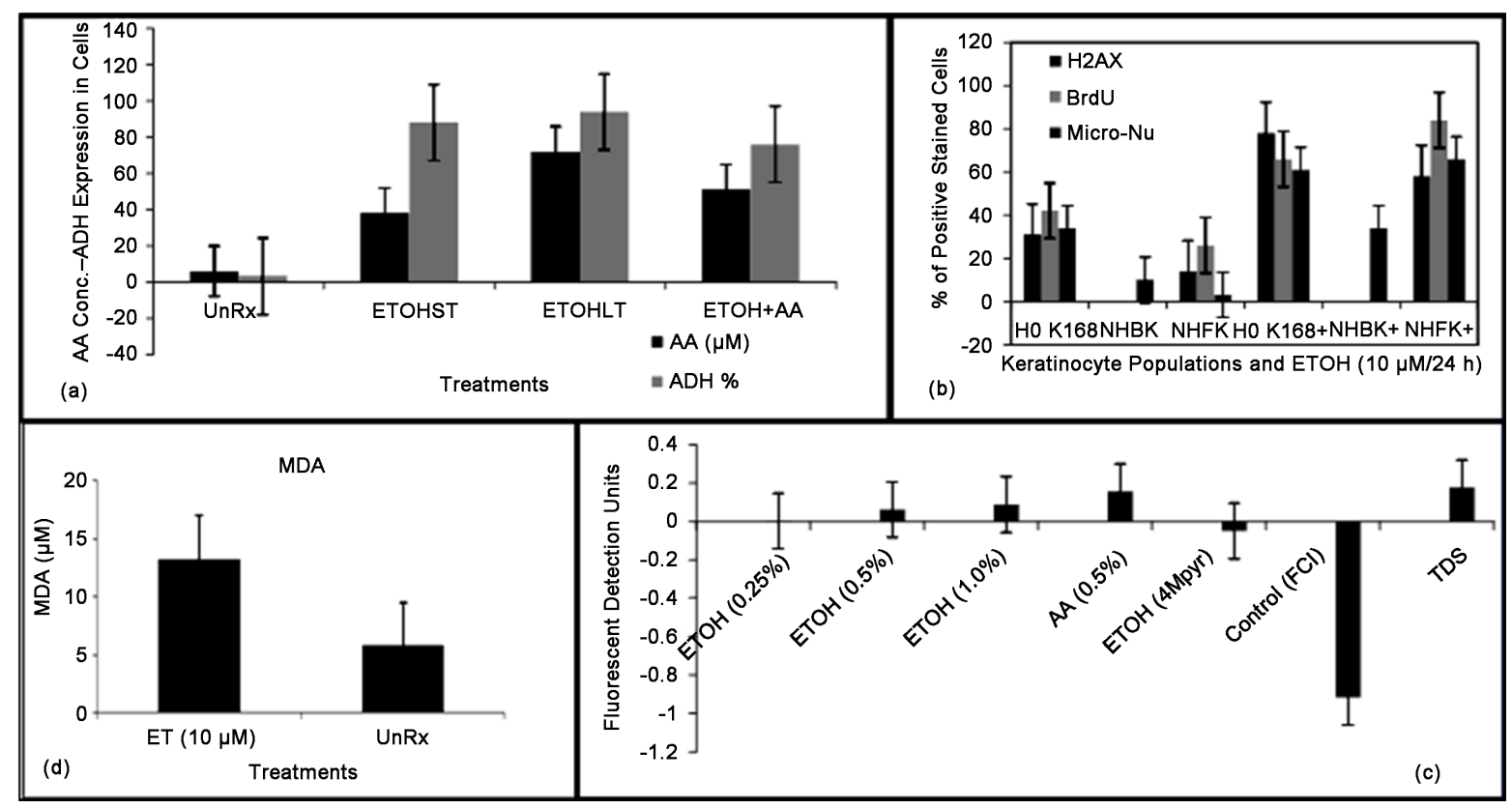

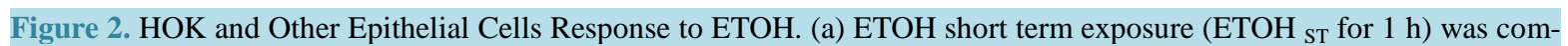
pared to longer term exposure $\left(\mathrm{ETOH}_{\mathrm{LT}}\right.$ for $\left.24 \mathrm{~h}\right)$. A significant increase in AA concentration and ADH expression was noted for each category compared to controls $\left(\mathrm{ETOH}_{\mathrm{ST}}\right.$ : AA $38 \pm 22.3 \mu \mathrm{M}$ : (p $\left.\leq 0.013\right)$; ADH: 85\% $\pm 35.6 \%$ : $(\mathrm{p}<0.0006)$; ETOHLT: AA $78 \pm 18.0 \mu \mathrm{M}$ : (p<0.0001); ADH 87\% $\pm 24.7 \%$ : $(\mathrm{p}<0.0001)$; ETOH ST+AA: AA $55 \pm 17.3 \mu \mathrm{M}:(\mathrm{p} \leq$ 0.0002); ADH 78\% \pm 33.0\%: ( $\leq$ 0.0009); (b) A variety of epithelial cells (HOK/HPV 16B; NHBK; NHFK) were examined for changes in H2AX expression an indication of double strand breaks; BrdU expression a marker for proliferation and micronuclei assessment; We compared the levels of H2AX, BrdU and micronuclei in the above cells with and without exposure to ETOH (10 $\mu \mathrm{M} / 24 \mathrm{~h})$. ETOH treatment enhanced the values for these tests. No treatment: HOK/HPV 16B. H2AX 34\% \pm 12.5\%; BrdU 41\% $\pm 12.0 \%$; Micronuclei. 37\% $\pm 15.5 \%$. ETOH treatment: HOK/HPV $16 \mathrm{~B}$. H2AX 78\% \pm 11.4\% ( $<$ 0.0001); BrdU 64\% $\pm 14.2 \%$ ( $\leq$ 0.0139); Micronuclei 58\% $\pm 14.2 \%$ ( $\leq 0.0344)$. No treatment: NHFK. H2AX 16\% \pm 9.8\%; BrdU 27\% \pm 10.1\%; Micronuclei $4.0 \% \pm 6.6 \%$, ETOH treatment NHFK. H2AX 56\% $\pm 12.5 \%(\mathrm{p}<$ $0.0001)$; BrdU 82\% $\pm 16.6 \%$ ( $<0.0001)$; Micronuclei $64 \% \pm 11.3 \%(\mathrm{p}<0.0001)$. NHBK are not in a proliferative state when harvested from buccal mucosa so we only examine micronuclei. No treatment: $12 \% \pm 8.0 \%$ in comparison to ETOH treatment: $34 \% \pm 8.3 \%$ ( < 0.0009); (c) ETOH treatments $(0.25 \% ; 2.5 \mathrm{mg} / \mathrm{mL}) ;(0.5 \%, 5 \mathrm{mg} / \mathrm{mL}) ;(1.0 \%, 10 \mathrm{mg} / \mathrm{mL})$; AA treatment $(0.5 \%, 5 \mathrm{mg} / \mathrm{mL})$; $4 \mathrm{Mpyr}$, inhibition of $\mathrm{ADH}$; inhibition of furin (FCI ), and inhibition of ALDH (TDS). Treatment effect on HPV 16 entry into 293TT epithelial cells was assessed. Results showed in comparison to baseline levels (see text) with an increase noted for ETOH and AA treatments while inhibitors 4Mpyr and FCI reduced HPV 16 entry. In contrast TDS effect is to increase AA concentration and this produced increased HPV 16 entry (see text); (d) MDA ( $\mu$ M) demonstrated ETOH metabolism by HOK/HPV 16B cells $(13.4 \% \pm 8.8 \%)$ compared to untreated HOK/HPV $16 \mathrm{~B}(6.2 \% \pm$ $7.4 \%)$ was increased but it was not significant $(\mathrm{p} \leq 0.1561)$. 
B) Percentage of HOK/HPV 16B cells positive for H2AX, BrdU, and micronuclei in comparison to other cell lines and primary keratinocytes were assessed and found to be enhanced following exposure to ETOH. Identification of gamma-H2AX demonstrates damage to chromosomes by assessing double stranded breaks while BrdU informs us about cell proliferation and micronuclei enumeration determines damage to chromosomes.

C) This assay evaluated the enhanced percentage of epithelial cells (293TT) that were identified with HPV 16 entry following ETOH and/or AA exposures, ADH (4 Mpyr), or ALDH inhibitions (TDS). Values for HPV 16 entry are compared to inhibition of FC following CMK (FCI).

D) The malonialdehyde (MDA) assay identified higher lipid peroxidation results from exposure to ETOH (ET).

a) Based upon the increase in percentage of cells in $\mathrm{G}_{2}+\mathrm{M}$ and associated with increased time exposure to ETOH we compared ETOH $(10 \mu \mathrm{M})(24 \mathrm{~h})$ to ETOH $(10 \mu \mathrm{M})(3 \mathrm{wk})$ for concentration changes in AA or percentage of ADH. Significantly all ETOH and AA treatments produced increases in comparison to unRx HOK/HPK 16 cells ( $<$ 0.001) (Figure 2).

b) The level of micronuclei in treated HOK/HPV 16B cells was significantly higher $(p<0.0001)$ than in treated fresh primary NHBK but this was not found for another primary cell, NKFK. In general, values for percentage of H2AX, BrdU and micronuclei increased with exposure to ETOH (10 $\mu \mathrm{M})$ for 24 h (Figure 2) compared to untreated values (e.g., from $20 \%$ - $40 \%$ to $60 \%$ - $80 \%$ ) (see legend for statistical evaluations).

c) A relationship between ETOH dose response (0.25\%, $0.53 \mu \mathrm{M} ; 0.5 \%, 1.07 \mu \mathrm{M} ; 1.0 \%, 2.15 \mu \mathrm{M})$, and HPV 16 entry into epithelial cells is noted and accentuated with AA treatment $(0.5 \%, 1.08 \mu \mathrm{M})(0.186$ Fluorescent Units). Use of 4 Mpyr reduced entry 8\% from the AA high treatment value in contrast to CMK (FCI) which suppressed 85\% HPV 16 entry from baseline. In contrast TDS increased HPV 16 entry in equivalence to $1.5 \mu \mathrm{M}$ of AA at 0.190 fluorescent units (Figure 2).

d) ETOH (5\%; $10 \mu \mathrm{M})$ above produced enhanced ploidy, DNA content, cell cycle, and damage. This damage is in accordance with the level of MDA which is $46.15 \%$ higher for ETOH treatment in comparison to untreated control value (Figure 2).

\subsection{Molecular Expressions Following ETOH or DBP Treatment of HOK/HPV 16B Cells}

Results from Figure 2 showed ETOH/AA changed HOK physiology and risk for HPV 16 entry events. In Figure 3 this latter result had us consider the cell molecular responses associated with this phenomenon to produce DNA damage agent from ETOH or another DNA damaging agent; the tobacco carcinogen, dibenzo[a,l]pyrene (DBP).

Figure 3(a) shows phosphorylated EGFR in three separate assay samples. In comparison to the control DMSO $(0.1 \mu \mathrm{M})$, which was used to dissolve DBP $(4 \mathrm{nM})$, we note an increase in phosphorylation by treatment with DBP (42.5\% densitometric units) and $10 \mu \mathrm{M}$ ETOH (54.8\% densitometric units).

Figure 3(b) shows results from assessment of multiple markers for regulation of cell cycle and growth for epithelial cells. We also studied the time effects for $\mathrm{ETOH}_{\mathrm{s}}$ incubation for $24 \mathrm{~h}$ and $\mathrm{ETOH}_{\mathrm{l}} 3$ wks. compared to $\mathrm{DBP}_{\mathrm{s}}$ incubation for $24 \mathrm{~h}$ and $\mathrm{DBP}_{\mathrm{L}} 3$ wks. The significant reductions noted were $\mathrm{DBP}_{1}\left(\mathrm{p} 16^{\mathrm{INK}} ; 24.7 \%\right.$ densitometric unit, p2 $7^{\mathrm{Kip} 1}$; 32.5\% densitometric units ) and $\mathrm{ETOH}_{1}\left(\mathrm{p} 27^{\mathrm{Kip} 1}, 72.1 \%\right.$ densitometric units). There was a general reduction in expression for c-Myc (59.8\% densitometric units; while an increase in expression for p21 ${ }^{\mathrm{Kip} 1}$ (mean 21.9\% densitometric units compared to NT control) and PAR1 (mean 33.5\% densitometric units compared to NT control). These results show a selective response by HPV/HOK 16B cells that produced an enhanced growth epidermal growth factor response following exposures to ETOH and DBP (Figure 3).

\subsection{Tobacco Associated Chemical and/or ETOH Effect upon HPV 16 Entry}

Having observed the effect of ETOH on HPV 16 (PsV) entry and molecular activity following ETOH or DBP treatments we assessed HPV 16 (PsV) entry for DBP (4 nM) and related tobacco carcinogens benzo[a]pyrene (B[a]P) (8.5 nM); nitrosoamines, NNK (207 nM) and NNAL (690 nM), and non-tobacco carcinogen, nicotine (255 nM); an important addictive agent in tobacco.

Figure 4(a) shows significant increases in HPV 16 entry with a comparison between controls and DBP (53.2\% +/- 10.4\%; p 0.0072); B[a]P (61.3\% +/- 13.0\%; < 0.0019); NNAL (84.7\% +/- 13.0\%; $\mathrm{p}<0.0001)$ and nicotine (12 mg) ( 62.5\% +/- 11,4\%; p 0.009) but not for NNK (44.7\% +/- 14.0\%; p 0.048 NS) in 293TT cells.

Figure 4(b) This interesting result as indicated was not performed with an oral keratinocyte population. To assess HPV 16 entry in regards to oral keratinocytes another assay was performed. Oral buccal cell (OBC), keratinocytes are placed under tissue culture conditions but these cells do not proliferate as their origin is from the 


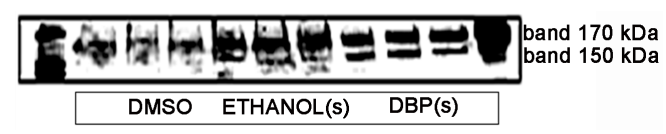

(a)

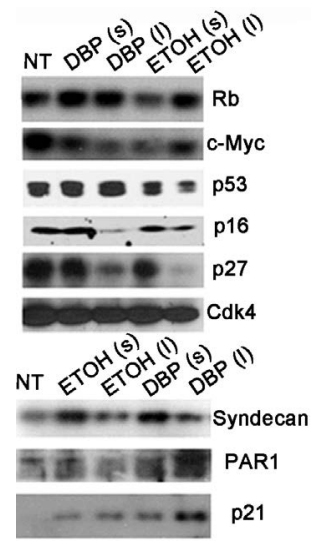

(b)

Figure 3. Molecular expressions following ETOH or DBP treatment of HOK/HPV 16B Cells. (a) Shows Western immunoblot detection of phosphorylated EGFR from three separate assays following exposure of HOK/HPV 16 from DMSO, ETOH $(10 \mu \mathrm{M})$ and DBP $(4 \mathrm{nM})$. Densitometric units (stated in text) demonstrated an enhanced expression of phosphorylated EGFR; (b) Demonstrated a selective enhancement or depression following $\mathrm{ETOH}_{s} / \mathrm{ETOH}_{1}$ or $\mathrm{DBP}_{s} / \mathrm{DBP}_{1}$ (densitometric units noted in text). $\mathrm{DBP}_{1}$ $\left(\mathrm{p} 16^{\mathrm{INK}} ; \mathrm{p} 27^{\mathrm{Kip} 1}\right)$ and $\mathrm{ETOH}_{1}\left(\mathrm{p} 27^{\mathrm{Kip} 1}\right)$ and in general a reduction in expression for c-Myc and p53 for ETOH compared to DBP; while in general an increase in expression for $\mathrm{p}_{21}{ }^{\mathrm{Kip} 1}$, PAR1, compared to NT control was also observed.

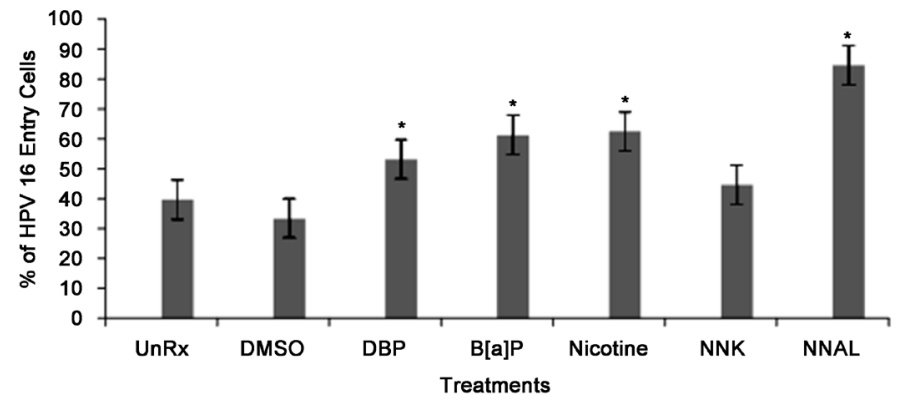

(a)

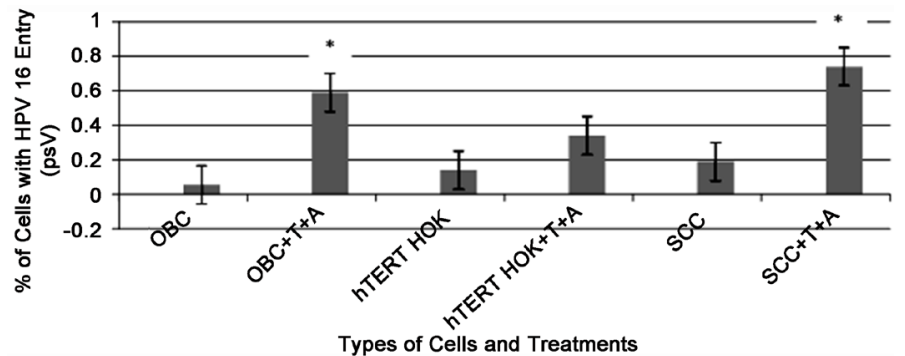

(b)

Figure 4. Tobacco associated chemical and/or ETOH effect upon HPV 16 Entry. (a) Exposure to DMSO and tobacco derived chemical such as nicotine and carcinogens for example, DBP, B[a]P, NNK and NNAL at doses and statistical significant evaluation (designated *) that showed an enhancement of HPV 16 entry compared to controls (see text); (b) Shows a statistical enhancement of HPV 16 entry for OBC and SCC-25 (SCC carcinoma cells) treated with ETOH and AA $(\mathrm{T}+\mathrm{A})$. Although increased levels for treated hTERT HOK was also recorded (see text). 
supra-basal region of the oral mucosa which is in contrast to cell lines; hTERT HOK, is an immortalized/nontumorigenic HOK and SCC-25, is a tongue OSCC. Treatment with tobacco (B[a]P) (T) and ethyl alcohol (A) enhanced HPV 16 entry particularly for OBC (59.4\% +/- 15.6\%; p < 0.002) and SCC-25 (74.4\% +/- 22\%; p < $0.001)$ cells while hTERT HOK cells treated with T+A enhanced HPV 16 entry but this effect was not significant (30.0\% +/- 22.0\%; $\mathrm{p} \leq 0.1218)$ (Figure 4).

\subsection{Comparative Enhancement of HPV 16 Entry Following Exposure to Anthraquinone or NNAL}

Figure 5 continued our studies using photomicrographs (see figure) and counts to demonstrate polycyclic aromatic hydrocarbon $(\mathrm{PAH})$ derivative anthraquinone $(\mathrm{p}<0.006)$ and nitrosamine $(\mathrm{NNAL})(\mathrm{p}<0.001)$ exhibited a comparative and parallel enhanced HPV 16 entry effect on 293TT.

\subsection{Cell Fractionation and Distribution of Furin in HOK/HPV 16B Cells Following Exposure to ETOH or DBP}

The above results of HPV 16 entry indicated a possible change in furin activity. We suspected this change in function is a product of expression and distribution of the proprotein convertases, furin, activity as discussed in the introduction. Furin is critical for HPV 16 entry and changes in its expression and cell distribution are expected to affect risk for infection.

HOK cells were fractionated into various cell compartments detailed in the legend for Figure 6. Following treatment with ETOH or DBP and Western immunoblot detection for furin there is noted to be a shift in localization of furin. For example, in untreated HOK regions: furin predominates in the cytoplasmic fraction (C), the cell membrane $(\mathrm{M})$ and reduced detection in nuclear $(\mathrm{N})$ membrane and to a less degree in cytoskeleton (S). In HOK/HPV 16 B cells treated with ETOH or DBP there is a clear shift to the cell membrane fraction. This result implies increased convertase activity circulation and deposition as furin accumulates at these sites. This result also increases possible chemical or physical communication of furin with a variety of cell organelle or membrane structures. For example accumulation of furin on the cell membrane may produce cooperation between furin and epidermal growth factor receptors (EGFR) (Figure 6).
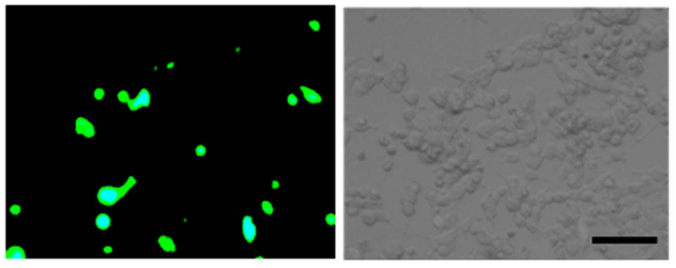

\section{DMSO Control}

$28.7 \%+/-10.4 \%$
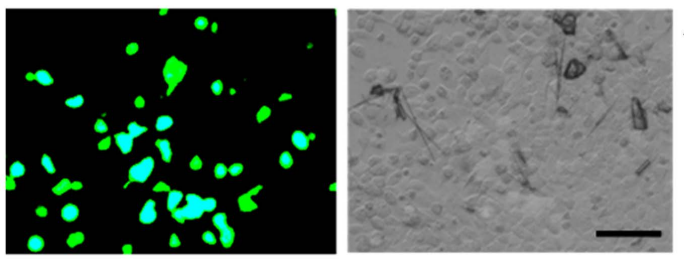

Anthraquinone (98 $\mathrm{nM})$

$56.4 \%+1-8.9 \%$

$(p<0.0006)$
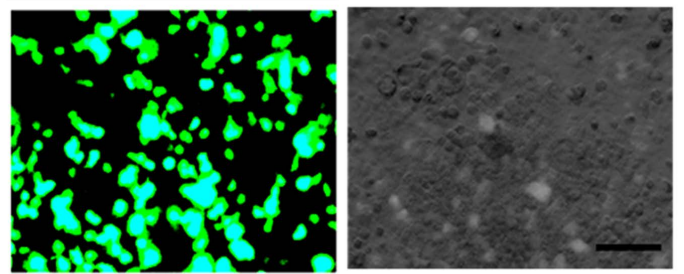

NNAL $(6.9 \mu \mathrm{M})$

$84.7 \%+/-9.0 \%$

$(p<0.0001)$

Figure 5. Comparative enhancement of HPV 16 entry following exposure to anthraquinone or NNAL. Additional photomicrographic examples of changes in HPV 16 entry is shown following exposure to DMSO, anthraquinone or NNAL. Both of the latter treatments produced statistical significant increases (see text). Insert $=10 \mu \mathrm{m}$. 


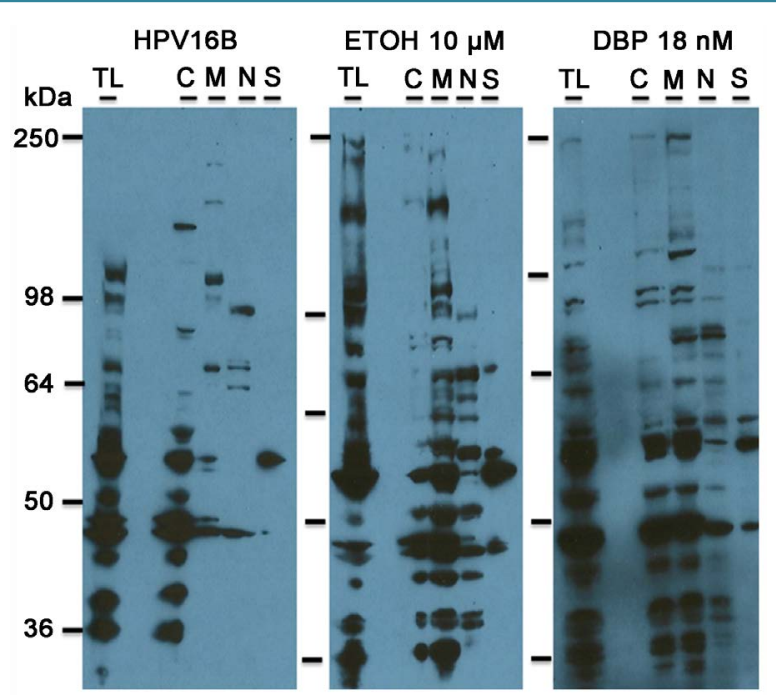

Figure 6. Cell Fractionation and Distribution of Furin in HOK/HPV 16B Cells Following Exposure to ETOH or DBP. Furin distribution was examined to obtain insight into characteristics of fuirn which is a proprotein convertase. Described in text is effects of ETOH $(10 \mathrm{mM})$ and DBP $(18 \mathrm{nM})$ after $24 \mathrm{~h}$ incubation with HOK/HPV 16B cells. In brief, these treatments shifted the accumulation of furin as detected by Western immunoblotting from total lysate (TL) to cell membrane (M), nuclear membrane (N) and cytoskeleton (S) and there appears to be a general enhanced circulation of furin.

\subsection{Effect of EGFR Inhibitors on Furin Related Activity for HPV 16 Entry}

To test this hypothesis we treated epithelial cells (293TT) with NNAL and EGFR inhibitors: Erlotinib or WZ4002 (Figure 7).

Figure 7(a) shows that entry of HPV 16 (PsV) was suppressed with Erlotinib treatment $(\mathrm{p}<0.003)$ but what was even more striking was a reduction in enhancement of HPV 16 entry following NNAL treatment (NNAL: $p$ $<0.001$ ) or a significant reduction when we co-exposed cells to both NNAL and Erlotinib (NNAL vs Erlotinib + NNAL: $\mathrm{p}<0.001$ ). This result suggested that this EGFR inhibitor could reverse a tobacco carcinogen membrane effect related to EGFR.

To validate this response a Western immunoblot was performed as seen in Figure 7(b) for furin expression. Only Erlotinib (Erb) and NNAL increased furin expression and as predicated from the above assay treatment with either Erlotinib (Erb) or WZ4002 (WZ), a $3^{\text {rd }}$ generation EGFR inhibitor, suppressed NNAL linked furin activity even though Erb by itself maintained a high level of furin expression.

\subsection{Time Effect on Proprotein Convertase Activity}

Cell associated proprotein convertase activity assays were conducted from one to three days following treatment with EGFR inhibitors and/or NNAL. Each day samples from exposures were tested from 10 to a maximum of 180 minutes. In addition on day three after exposure to EGFR inhibitors and/or NNAL we assessed HPV 16 entry (PsV) to note this function in-conjunction with convertase activity (see Material and Methods Section).

Day one a convertase activity was found for 293TT cells to increase with DMSO treatment from 10 minutes to $240 \mathrm{~min}$. This time effect for each day was noted not only for DMSO but also other treatments that effect EGFR. For example, inhibitors and/or NNAL (Figure 8). The highest level for any treatment on any day was attained from NNAL compared to DMSO control (a). In general Erlotinib (Erb) treatment had higher levels of induction of convertase activity compared to WZ40002 (WZ) and this was noted over time for day one or two compared to our DMSO control. On day one or two following WZ treatment a generally lower convertase level than Erlotinib treatment produced was recorded. However, for all days of incubation and times a combination of NNAL and EGFR inhibitors reduced convertase activity below values for the DMSO control. This pattern was reproduced with the HPV 16 entry (PsV) assay (b) and was in general recapitulated for hTERT HOK (c).

These assays substantiated a relationship between tobacco derived carcinogen, NNAL and EGFR inhibitors that reduced phosphorylated EGFR and furin expressions resulting in less early HPV 16 entry (Figure 8). 


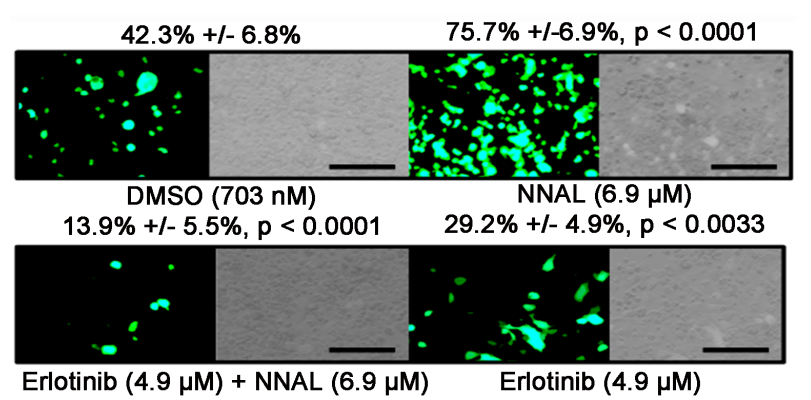

(a)

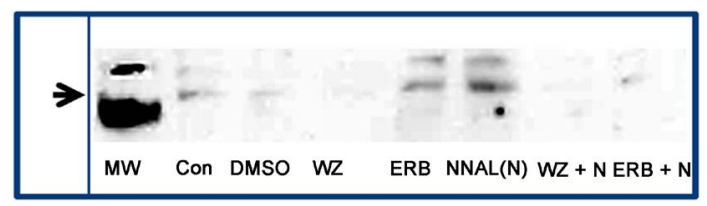

(b)

Figure 7. Effect of EGFR inhibitors on furin related activity for HPV 16 entry. (a) Photomicrographs show the relationship between NNAL; Erlotinib, a EGFR inhibitor; and Erlotinib + NNAL treatments. Concentrations are given on the figure and exposure for epithelial cells (293TT) was for 7d. Images and quantitation indicated NNAL enhanced HPV 16 entry while a combined treatment significantly reduced HPV 16 entry (see text). Insert= $10 \mu \mathrm{m}$; (b) Furin expression was documented using a Western immunoblot. Results shown are comparative enhanced levels for NNAL (N) and Erlotinib (ERB) induced furin levels in comparison to ERB + N, which parallels (a) findings. In addition WZ4002 (WZ) reduced NNAL effect on furin expression to a level recorded for only WZ.

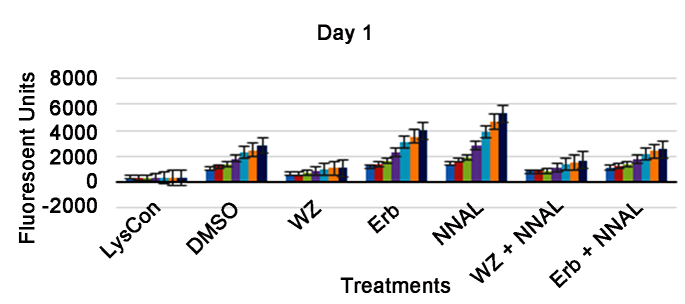

(a)

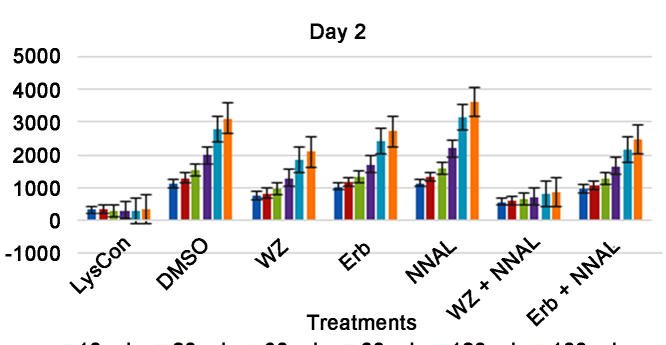

$₫ 10 \mathrm{~min}=20 \mathrm{~min}=30 \mathrm{~min}=60 \mathrm{~min}=120 \mathrm{~min}=180 \mathrm{~min}$

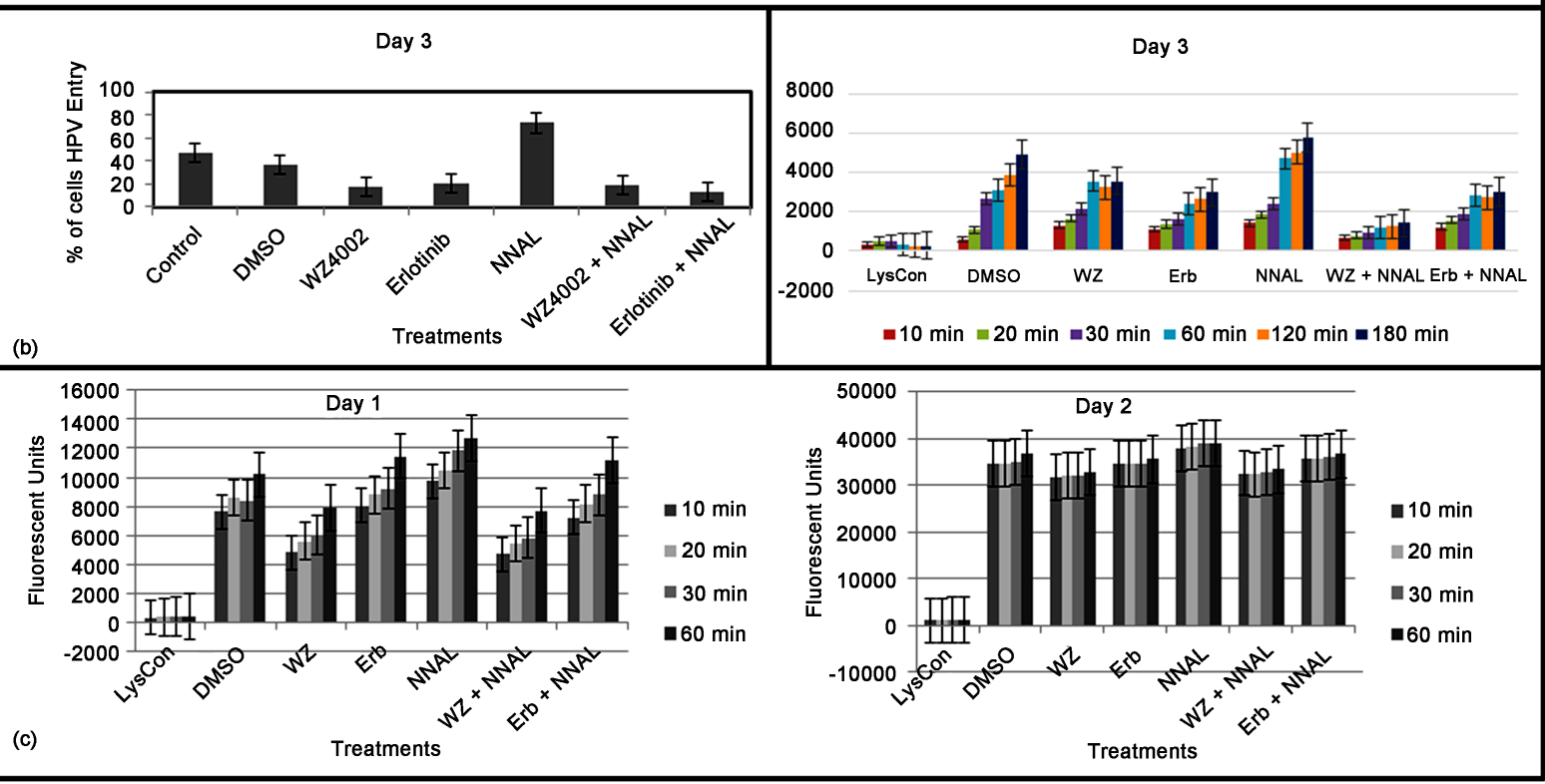

Figure 8. Time effect on proprotein convertase activity. (a) An examination of convertase activity was conducted for three days at time intervals of 10 minutes to 240 minutes. This series of assays substantiated findings recorded in Figure 7 that NNAL elevates convertases such as furin. In addition we note that on day 1 through day 3 forWZ4002 (WZ) or Erlotinib (ERB) treatments suppresses NNAL capability to increase convertase activity; (b) In comparison the HPV 16 entry produced a similar increase response with increased convertase while WZ and ERB suppressed HPV 16 entry; (c) Demonstrated a similar pattern (10 to $60 \mathrm{~min}$.) of convertase activity day 1and day 2 for hTERT HOK cells but not to the same levels previously stated above. 


\section{Discussion}

The results demonstrate that environmental agents such as ETOH/AA or tobacco derived chemicals alter growth of epithelial and a variety of HOK cells (Figure 1; Figure 2 and Figure 4). Previous reports are coincident with our findings, to show ethyl alcohol caused a $\mathrm{G}_{2}+\mathrm{M}$ cell cycle arrest [54]. This relationship implies DNA damage disclosed in Figure 2(b), from lipid peroxidation (MDA) (Figure 2(d)) results in a loss of growth regulation. Change in $\mathrm{G}_{1}$ was demonstrated by our cell cycle (Figure 1) and Western immunoblot results that showed a reduction in p16 ${ }^{\text {WAF/CIP1 }}$ which normally inhibits cyclin dependent kinase 4 (CDK4). CDK4 and also enhances tumor suppressor activity through phosphorylation of retinoblastoma gene product (Rb) [55]. To support this notion we note a small reduction in phosphorylated RB following ETOH exposure of HOK/HPV 16B cells (Figure 3(b)). Similarly, exposure of oral mucosa and keratinocytes to tobacco derived carcinogens such as dibenzo[a,l]pyrene (DBP) is shown to also alter cell cycle regulation and manifest enhanced growth that can result in OSCC [56]. OSCC is thought to be a product of inappropriate enhanced growth/signaling from lack of cyclin kinase regulation and tumor suppressor function to mediate enhanced EGFR activity. It is interesting to note membrane-anchored growth factors, for the epidermal growth factor family includes metalloproteinases which are important drivers of cancer cell proliferation because of CDK4 activation and retinoblastoma protein (Rb) inactivation [57]. Moreover, change in growth of HOK is associated with additional nuclear change as indicated above with selective molecular changes that regulate cell cycle/growth (Figure 1(b), Table 1, and p16; p27 ${ }^{\mathrm{KIP}}$; p21 ${ }^{\text {WAF1/CIP }}$, and PAR1 (Figure 3)). We note, up-regulation of p21 ${ }^{\text {WAF1/CIP }}$ with EGFR enhanced expression in this study (Figure 3) and in recent reports [58] [59].

Other studies have also indicated a positive relationship between protease activated receptor 1 (PAR1) and EGFR expression [60]. Furthermore, it is evident that EGFR is linked to PAR1 function through use of inhibitors such as, phospho-tyrosine inhibitor, Erlotinib that suppresses EGFR and PAR1 inhibitor and indicates another approach to regulate epithelial cell growth [61].

We also observed an expression effect not only for EGFR but an effect upon HPV 16 entry. This latter event was derived from a change in accumulation of furin at other than membrane sites in HOK (Figure 6). We suggest the initial target of environmental factors; ETOH or DBP is cell membrane EGFR phosphorylation and functional furin expression (Figures 6-8). This was considered here because of a previous indication that EGFR enhanced expression was responsive to exogenous agents and microbial factors to produce an additional enhancement of HPV 16 entry [13]. In this study we support this concept with further evidence of EGFR interaction with furin. We disclose effects from exogenous factor exposures: ETOH/AA; and tobacco product derived chemicals to enhance EGFR expression while we recorded the furin expression dependence on HPV 16 entry. Our evidence included Western immunoblotting expression for EGFR and furin; use of EGFR inhibitors, furin inhibition; changes in furin activity and distribution in a HPV 16 infected HOK cell (HOK/HPV 16B) exposed to either ETOH or DBP (Figures 2-8). Moreover a chemical similarity between EGFR and furin may exist as evidenced by a cysteine rich sequence in both EGFR and furin active domain and this could imply a similar redox response [21].

EGFR response to tobacco derived oxidative agents such as nitrosamine, NNAL is presented in Figure 7 and Figure 8. We show EGFR inhibitor Erlotinib markedly reduced NNAL capacity to enhance furin and as identified using Western immunoblotting with an increase in HPV 16 entry. This was confirmed through a proprotein convertase assay that used both epithelial cells, 293TT and hTERT HOK; performed on days one to three over 10 to 240 minutes which shows the dynamics of the convertase enzyme-substrate interaction (Figure 8).

There are many articles that demonstrate first, second and third generation EGFR inhibition in a variety of carcinomas, which includes head and neck and OSCC [62] [63]. However, a library internet search showed only one study with human oral mucosa derived cells. These cells were exposed to tobacco carcinogen to produce DNA damage and enhanced EGFR expression. Inhibition of EGFR also suppressed DNA damage [64]. In addition one study of experimental oral carcinogenesis showed inhibition of EGFR also suppressed DNA damage [65]. In treatment settings EGFR inhibitors such as cetuximab have been used with an alkylating agent; such as, cisplatin.

In a recent report, Pogorzelski et al., observed that "endogenous HPV status or the expression of HPV oncogenes had no significant impact on cetuximab-mediated suppression of EGFR signaling and proliferation in vitro. However, they did not consider whether cetuximab has the expected suppression of furin convertase and HPV 16 infection on a prevention basis and there was no examination of inhibition of early HPV infection in 
comparison to non-episomal HPV genomic incorporation [66]. Using a retrospective analysis approach another treatment evaluation group showed variability in HPV level and responses to EGFR inhibition from cetuximab in oropharyngeal carcinoma (OPC). OPC has a high degree of association risk with HPV 16 infection with about $70 \%$ of these carcinomas HPV 16 related (e.g., in some cases p16 positivity was also documented). They had two conclusions for HPV 16 related OPC: 1 ) HPV levels in OPC are in an inverse ratio to EGFR high copy number and over expression, which implies less response to cetuximab. 2) However, in a subset of OPC there is a high EGFR expression that is responsive to cetuximab but addition studies are needed because of a high degree of variability that is present [67].

This latter review also did not address the concept described above that EGFR inhibitors should be considered as prevention agents that reduce EGFR pathway activation and suppresses both HPV 16 infection and malignant transformation risk with an expected reduction in furin activity [68] [69]. Furthermore, there have been discovered several chemical means to suppress furin activity in conjunction with a reduced HPV 16 entry into keratinocytes. In this study we used CMK but Kwak et al. described use of heparin and carrageenan to prevented infection by mucosa-tropic HPV subtypes [70]. Additional formulations may be suggested with combinations with various EGFR inhibitors also described in this study.

\section{Conclusion}

Exogenous chemicals substance from environmental exposure or habits (e.g., ETOH or tobacco derived chemicals) will induce molecular and physiologic change to HOK. One particular effect is to enhance phosphorylated EGFR expression. However EGFR inhibitors appear to be capable of suppressing not only growth of transformed HOK through suppression of EGFR by these inhibitors but also prevent HPV 16 entry as a reduction in furin activity occurs. This latter effect also promotes the hope for inhibition of clinical dermatologic diseases of HOKs related to HPV infection.

\section{Acknowledgements}

We acknowledge assistance of Nancy Norman for help with editing this manuscript. We also acknowledge Dr. Martin Muller from the German Cancer Research Center as the provider of pShell16.

\section{Competing Interest}

None declared.

\section{Fund}

Funds through a competitive funded grant. The funding source had no involvement in publication. PI: Joel Schwartz UIC Cancer Center: "Early Detection, Diagnosis, and Genetic Susceptibility for Oral and Oral Pharynx Cancer Among Diverse Populations”.

\section{References}

[1] Xia, W., Lau, Y.K., Zhang, H.-Z., Xiao, F.-Y., Johnston, D.A., Liu, L., Katz, R.L. and Hung, M.-C. (1999) Combination of EGFR, HER-2/Neu and HER-3 Is a Stronger Predicator for Outcome of Oral Squamous Cell Carcinoma than Any Individual Family Members. Clinical Cancer Research, 5, 4164-4174.

[2] Ching, S., Low, I., Ng, D., Brasch, H., Sullivan, M., Davis, P. and Tan, S.T. (2008) Epidermal Growth Factor Receptor: A Novel Biomarker for Aggressive Head and Neck Cutaneous Squamous Cell Carcinoma. Human Pathology, 39, 344349. http://dx.doi.org/10.1016/j.humpath.2007.07.004

[3] Thomas, L., Moore, E.J., McGree, M.E., Olsen, K.D., Kasperbauer, J.L., Erickson, L.A. and Schembri-Wismayer, D.J. (2012) Prognostic Features, Human Papillomavirus Status and Epidermal Growth Receptor Expression in Oral Squamous Cell Carcinoma in Young Adults. American Journal of Otolaryngology, 33, 650-656. http://dx.doi.org/10.1016/j.amjoto.2012.01.009

[4] Cripps, C., Winquist, E., Devries, M.C., Stys-Norman, D. and Gilbert, R. (2010) Epidermal Growth Factor Receptor Targeted Therapy in Stages II and IV Head and Neck Cancer. Current Oncology, 17, 37-48. http://dx.doi.org/10.3747/co.v17i3.520

[5] Goffin, J.R. and Zbuk, K. (2013) Epidermal Growth Factor Receptor: Pathways, Therapies and Pipeline. Clinical The- 
rapeutics, 9, 1282-1303. http://dx.doi.org/10.1016/j.clinthera.2013.08.007

[6] Carpenter, G. (1987) Receptors for Epidermal Growth Factor and Other Polypeptide Mitogens. Annual Review of Biochemistry, 56, 881-914. http://dx.doi.org/10.1146/annurev.bi.56.070187.004313

[7] Kelloff, G.J., Fay, J.R., Steele, V.E., Lubet, R.A., Boone, C.W. and Crowell, J.A. (1996) Epidermal Growth Factor Receptor Tyrosine Kinase Inhibitors as Potential Cancer Chemopreventives. Cancer Epidemiology, Biomarkers \& Prevention, 5, 657-666.

[8] Yewale, C., Baradia, D., Vhora, I., Patil, S. and Misra, A. (2013) Epidermal Growth Factor Receptor: Targeting in Cancer: A Review of Trends and Strategies. Biomaterials, 34, 8690-8707. http://dx.doi.org/10.1016/j.biomaterials.2013.07.100

[9] Pastore, S., Mascia, F., Mariani, V. and Girolomoni, G. (2007) The Epidermal Growth Factor Receptor System in Skin Repair and Inflammation. The Society for Investigative Dermatology, 128, 1365-1374. http://dx.doi.org/10.1038/sj.jid.5701184

[10] Schneider, M.R. and Wolf, E. (2009) The Epidermal Growth Factor Receptor Ligands at a Glance. Journal of Cellular Physiology, 218, 460-466. http://dx.doi.org/10.1002/jcp.21635

[11] Higashiyama, S., Iwabuki, H., Morimoto, C., Hieda, M., Inoue, H. and Matsushita, N. (2008) Membrane-Anchored Growth Factors, the Epidermal Growth Factor Family: Beyond Receptor Ligands. Cancer Science, 99, 214-220. http://dx.doi.org/10.1111/j.1349-7006.2007.00676.x

[12] Konda, Y., Yokota, H., Kayo, T., Horiuchi, T., Sugiyama, N., Tanaka, S., Takata, K. and Takeuchi, T. (1997) Proprotein-Processing Endoprotease Furin Controls the Growth and Differentiation of Gastric Surfaces Mucous Cells. Journal of Clinical Investigation, 99, 1842-1851. http://dx.doi.org/10.1172/JCI119351

[13] Schwartz, J., Izaquirre, G., Pavlova, S., Sroussi, H., Lu, Y., Munaretto, A., Crowe, D. and Tao, L. (2014) Alcohol Treatment of Oral Streptococcus spp. Increased the Entry of Human Papillomvirus Type 16 into Non-Malignant and Oral Squamous Cell Carcinoma Cells. Journal of Oral Biology, 1, 12.

[14] Nakatani, Y., Yamazaki, M., Chazin, W.J. and Yui, S. (2005) Regulation of S100A8/A9 (Calprotectin) Binding to Tumor Cells by Zinc Ion and Its Implication for Apoptosis-Inducing Activity. Mediators of Inflammation, 5, $280-292$. http://dx.doi.org/10.1155/MI.2005.280

[15] Donate, R., Cannon, B.R., Sorci, G., Riuzzi, F., Hsu, K., Weber, D.J. and Geczy, C.L. (2013) Functions of S100 Proteins. Current Molecular Medicine, 13, 24-57. http://dx.doi.org/10.2174/156652413804486214

[16] Inki, P., Joensuu, H., Grenman, R., Klemi, P. and Jalkanen, M. (1994) Association between Syndecan-1 Expression and Clinical Outcome in Squamous Cell Carcinoma of the Head and Neck. British Journal of Cancer, 70, 319-323. http://dx.doi.org/10.1038/bjc.1994.300

[17] Omar, A.A.H., Haglund, C., Virolainen, S., Hayry, V., Atula, T., Kontio, R., Rihtniemi, J., Pihakari, A., Salo, T., Hagstrom, J. and Sorsa, T. (2013) Epithelial and Stromal Syndecan-1 and -2 Are Distinctly Expressed in Oral and Cutaneous Squamous Cell Carcinomas. Journal of Oral Pathology \& Medicine, 42, 389-395. http://dx.doi.org/10.1111/jop.12025

[18] Kerkoff, C., Nacken, W., Benedyk, M., Dagher, N.C., Sopalla, C. and Doussiere, J. (2005) The Arachidonic AcidBinding Protein S100 A8/A9 Promotes NADPH Oxidase Activation by Interaction with p67 ${ }^{\text {phox }}$ and Rac-2. The FASEB Journal. http://dx.doi.org/10.1096/fj.04-2377fje

[19] Blobel, C.P. (2005) ADAMS: Key Components in EGFR Signaling and Development. Nature, 6, 32-43.

[20] Schlomann, U., Wildeboer, D., Webster, A., Antropova, O., Zeuschner, D., Knight, C.G., Docherty, A.J.P., Lambert, M., Skelton, L., Jockusch, H. and Bartsch, J.W. (2002) The Metalloprotease Disintegrin ADAM8. Journal of Biological Chemistry, 277, 48210-48219. http://dx.doi.org/10.1074/jbc.M203355200

[21] Abe, Y., Odaka, M., Inagaki, F., Lax, I., Schlessinger, J. and Kohda, D. (1998) Disulfide Bond Structure of Human Epidermal Growth Factor Receptor. The Journal of Biological Chemistry, 273, 11150-11157. http://dx.doi.org/10.1074/jbc.273.18.11150

[22] Bassi, D.E., De Cicco, R.C., Mahloogi, H., Zucker, S., Thomas, G. and Klein-Szanto, A.J.P. (2001) Furin Inhibition Results in Absent or Decreased Invasiness and Tumorigenicity of Human Cancer Cells. Proceedings of the National Academy of Sciences of the United States of America, 98, 10326-10331. http://dx.doi.org/10.1073/pnas.191199198

[23] Seidah, N.G. (2011) What Lies Ahead for the Proprotein Convertase? Annals of the New York Academy of Sciences, 1220, 149-161. http://dx.doi.org/10.1111/j.1749-6632.2010.05883.x

[24] Bassi, D.E., De Cicco, R.C. and Klein-Szanto, A.J.P. (2005) Proprotein Convertases: "Master Switches” in the Regulation of Tumor Growth and Progression. Molecular Carcinogenesis, 44, 151-161. http://dx.doi.org/10.1002/mc.20134

[25] Vidricaire, G., Denault, J.B. and Leduc, R. (1993) Characterization of a Secreted form of Human Furin Endoprotease. Biochemical and Biophysical Communications, 195, 1011-1018. http://dx.doi.org/10.1006/bbrc.1993.2145 
[26] Roebroek, A.J., Schalken, J.A., Leunissen, J.A., Onnekink, C., Bloemers, H.P. and Van de Ven, W.J. (1986) Evolutionary Conserved Close Linkage of the C-fes/fps Proto-Oncogene and Genetic Sequences Encoding a Receptor-Like Protein. The EMBO Journal, 16, 4938-4950.

[27] Roghani, M., Becherer, J.D., Moss, M.L., Atherton, R.E., Erdjument-Bromage, H., Arribas, J., Blackburn, R.K., Weskamp, G., Temst, P. and Blobel, C.P. (1999) Metalloprotease-Disintegrin MDC9: Intracellular Maturation and Catalytic Activity. The Journal of Biological Chemistry, 272, 3531-3540. http://dx.doi.org/10.1074/jbc.274.6.3531

[28] Wolf, E. (2009) The Epidermal Growth Factor Receptor Ligands at a Glance. Journal of Cellular Physiology, 218, 460-466. http://dx.doi.org/10.1002/jcp.21635

[29] Kwak, K., Jiang, R., Wang, J.W., Jagu, S., Kirnbauer, R. and Roden, R.B.S. (2014) Impact of Inhibitors and L2 Antibodies upon the Infectivity of Diverse Alpha and Beta Human Papillomavirus Types. PLoS ONE, 9, 1-11. http://dx.doi.org/10.1371/journal.pone.0097232

[30] Day, P.M. and Schiller, J.T. (2009) The Role of Furin in Papillomavirus Infection. Future Microbiology, 4, $1255-1262$. http://dx.doi.org/10.2217/fmb.09.86

[31] Richards, R.M., Lowy, D.R., Schiller, J.T. and Day, P.M. (2006) Cleavage of the Papillomavirus Minor Capsid Protein L2 at a Furin Consensus Site Is Necessary for Infection. Proceedings of the National Academy of Sciences of the United States of America, 103, 1522-1527. http://dx.doi.org/10.1073/pnas.0508815103

[32] Lokman, N.A., Ween, M.P., Oehler, M.K. and Ricciardelli, C. (2011) The Role of Annexin A2 in Tumorigenesis and Cancer Progression. Cancer Microenvironment, 4, 199-208. http://dx.doi.org/10.1007/s12307-011-0064-9

[33] Raff, A.B., Woodham, A.W., Raff, L.M., Skeate, J.G., Yan, L., Da Silva, D.M., Schelhaas, M. and Kast, W.M. (2013) The Evolving Field of Human Papillomavirus Receptor Research: A Review of Binding and Entry. Journal of Virology, 87, 6062-6072. http://dx.doi.org/10.1128/JVI.00330-13

[34] Sketty, P.K., Thake, S.I., Biswas, S., Johansson, S.L. and Vishwanatha, J.K. (2012) Reciprocal of Annexin A2 and EGFR with Her-2 in Her-2 Negative and Herceptin-Resistant Breast Cancer. PLoS ONE, 7, e44299. http://dx.doi.org/10.1371/journal.pone.0044299

[35] Mistry, N., Wibom, C. and Evander, M. (2008) Cutaneous and Mucosal Human Papillomaviruses Differ in Net Surface Charge, Potential Impact on Tropism. Virology Journal, 5,118-126. http://dx.doi.org/10.1186/1743-422X-5-118

[36] Ishii, Y., Makahara, T., Kataoka, M., Kusumoto-Matsuo, R., Mori, S., Takeuchi, T. and Kukimoto, I. (2013) Identification of TRAPPC8 as a Host Factor Required for Human Papillomavirus Cell Entry. PLoS ONE, 8, e80297.

[37] Yunta, M. and Lazo, P.A. (2003) Tetraspanin Proteins as Organizers of Membrane Microdomains and Signaling Complexes. Cellular Signalling, 15, 559-564. http://dx.doi.org/10.1016/S0898-6568(02)00147-X

[38] Truong, T.H. and Carroll, K.S. (2012) Redox Regulation of EGFR Signaling through Cysteine Oxidation. Biochemistry, 51, 9954-9965. http://dx.doi.org/10.1021/bi301441e

[39] Zakhari, S. (2013) Alcohol Metabolism and Epigenetics Changes. Alcohol Research, 35, 6-16.

[40] Hoffman, A.C. and Evans, S.E. (2013) Abuse Potential of Non-Nicotine Tobacco Smoke Components: Acetaldehyde, Nornicotine, Cotinine, and Anabasine. Nicotine Tobacco Research, 15, 622-632. http://dx.doi.org/10.1093/ntr/nts192

[41] Meurman, J.K. (2010) Oral Microbiota and Cancer. Journal of Oral Microbiology, 2, 5195.

[42] Vitale-Cross, L., Czerninski, R., Amornphimoltham, P., Patel, V., Molinolo, A.A. and Gutkind, J.S. (2009) Chemical Carcinogenesis Models for Evaluating Molecular-Targeted Prevention and Treatment of Oral Cancer. Cancer Prevention Research, 2, 419-422. http://dx.doi.org/10.1158/1940-6207.CAPR-09-0058

[43] Kupferman, M.E. and Myers, J.N. (2006) Molecular Biology of Oral Cavity Squamous Cell Carcinoma. Otolaryngologic Clinics of North America, 39, 229-247. http://dx.doi.org/10.1016/j.otc.2005.11.003

[44] Husain, Q. and Qayyum, S. (2013) Biological and Enzymatic Treatment of Bisphenol A and Other Endocrine Disrupting Compounds: A Review. Critical Reviews in Biotechnology, 33, 260-292.

[45] Zhang, L., Jin, Y., Huang, M. and Penning, T.M. (2012) The Role of Human Aldo-Keto Reductases in the Metabolic Activation and Detoxication of Polycyclic Aromatic Hydrocarbons: Interconversion of PAH Catechols and PAH o-Quinones. Frontiers in Pharmacology, 16, 193.

[46] Yokoyama, A. and Omori, T. (2005) Genetic Polymorphisms of Alcohol and Aldehyde Dehydrogenase and Risk for Esophageal and Head and Neck Cancers. Alcohol, 35, 175-185. http://dx.doi.org/10.1016/j.alcohol.2005.04.003

[47] Lieber, C.S. (1987) Metabolic Effects of Acetaldehyde. Biochemical Society Transactions, 16, 241-247.

[48] Avezvov, K., Resnick, A.Z. and Aizenbud, D. (2014) Oxidative Damage in Keratinocytes Exposed to Cigarette Smoke and Aldehydes. Toxicology in Vitro, 28, 485-491. http://dx.doi.org/10.1016/j.tiv.2014.01.004

[49] Fenech, M. (2000) The in Vitro Micronucleus Technique. Mutation Research, 455, 81-95. http://dx.doi.org/10.1016/S0027-5107(00)00065-8 
[50] Schwartz, J., Pavlova, S., Kolokythas, A., Lugakingira, M., Tao, L. and Miloro, M. (2012) Streptococci-Human Papilloma Virus Interaction with Ethanol Exposure Leads to Keratinocyte Damage. Journal of Oral and Maxillofacial Surgery, 70, 1867-1879. http://dx.doi.org/10.1016/j.joms.2011.08.005

[51] Buck, C.B., Thompson, C.D., Roberts, J.N., Müller, M., Lowy, D.R. and Schiller, J.T. (2006) Carrageenan Is a Potent Inhibitor of Papillomavirus Infection. PLoS Pathogens, 2, e69. http://dx.doi.org/10.1371/journal.ppat.0020069

[52] Buck, C.B., Pastrana, D.V., Lowy, D.R. and Schiller, J.T. (2004) Efficient Intracellular Assembly of Papillomaviral Vectors. Journal of Virology, 78, 751-757. http://dx.doi.org/10.1128/JVI.78.2.751-757.2004

[53] Buck, C.B., Thompson, C.D., Pang, Y.Y., Lowy, D.R. and Schiller, J.T. (2005) Maturation of Papillomavirus Capsids. Journal of Virology, 79, 2839-2846. http://dx.doi.org/10.1128/JVI.79.5.2839-2846.2005

[54] Clemens, D.L., Calisto, L.E., Sorrell, M.F. and Tuma, D.J. (2003) Ethanol Metabolism Results in a G2/M Cell-Cycle Arrest in Recombinant Hep G2 Cells. Hepatology, 38, 385-393. http://dx.doi.org/10.1053/jhep.2003.50332

[55] Sheppard, K.E. and McArthur, G.A. (2013) The Cell-Cycle Regulator CDK4: An Emerging Therapeutic Target in Melanoma. Clinical Cancer Research, 19, 5320-5328. http://dx.doi.org/10.1158/1078-0432.CCR-13-0259

[56] Chen, K.M., Guttenplan, J.B., Zhang, S.M., Aliaga, C., Cooper, T.K., Sun, Y.W., Del Tondo, J., Kosinska, W., Sharma, A.K., Jiang, K., Bruggeman, R., Ahn, K., Amin, S. and El-Bayoumy, K. (2013) Mechanisms of Oral Carcinogenesis Induced by Dibenzo[a,l]pyrene: An Environmental Pollutant and a Tobacco Smoke Constituent. International Journal of Cancer, 133, 1300-1309. http://dx.doi.org/10.1002/ijc.28152

[57] Paye, A., Truong, A., Yip, C., Jonathan, C., Blacher, S., Munaut, C., Catado, D., Foidart, J.M., Maquoi, E., Collignon, J., Delvenne, P., Jerusalem, G., Noel, A. and Sounni, N.E. (2014) EGFR Activation and Signaling in Cancer Cells Are Enhanced by the Membrane-Bound Metalloprotease MT4-MMP. Cancer Research, 74, 6758-6770.

[58] Wei, W., Chen, Z.J., Zhang, K.S., Yang, X.L., Wu, Y.M., Chen, X.H., Huang, H.B., Liu, H.L., Cai, S.H., Du, J. and Wang, H.S. (2014) The Activation of G Protein-Coupled Receptor 30 (GPR30) Inhibits Proliferation of Estrogen Receptor-Negative Breast Cancer Cells in Vitro and in Vivo. Cell Death Disease, 5, e1428.

[59] Song, W., Dang, Q., Xu, D., Chen, Y., Zhu, G., Wu, K., Zeng, J., Long, Q., Wang, X., He, D. and Li, L. (2014) Kaempferol Induces Cell Cycle Arrest and Apoptosis in Renal Cell Carcinoma through EGFR/p38 Signaling. Oncology Reports, 31, 1350-1356. http://dx.doi.org/10.3892/or.2014.2965

[60] Huang, C.Y., Lin, H.J., Chen, H.S., Cheng, S.Y., Hsu, H.C. and Tang, C.H. (2013) Thrombin Promotes Matrix Metalloproteinase-13 Expression through the PKC $\delta / \mathrm{c}-S r c / E G F R / P I 3 K / A k t / A P-1$ Signaling Pathway in Human Chondrocytes. Mediators of Inflammation, 2013, 1-12. http://dx.doi.org/10.1155/2013/326041

[61] Ohshiro, K., Bui-Nguyen, T.M., Divijendra Natha, R.S., Schwartz, A.M., Levine, P. and Kumar, R. (2012) Thrombin Stimulation of Inflammatory Breast Cancer Cells Leads to Aggressiveness via the EGFR-PAR1-Pak1 Pathway. The International Journal of Biological Markers, 27, e305-e313. http://dx.doi.org/10.5301/JBM.2012.10437

[62] Ribeiro, F.A., Noguti, J., Oshima, C.T. and Ribeiro, D.A. (2014) Effective Targeting of the Epidermal Growth Factor Receptor (EGFR) for Treatment of Oral Cancer: A Promising Approach. Anticancer Research, 34, 1547-1552.

[63] Cohen, R.B. (2014) Current Challenges and Clinical Investigations of Epidermal Growth Factor Receptor (EGFR)- and ErbB Family-Targeted Agents in the Treatment of Head and Neck Squamous Cell Carcinoma (HNSCC). Cancer Treatment Reviews, 40, 567-577. http://dx.doi.org/10.1016/j.ctrv.2013.10.002

[64] Baumeister, P., Heinrich, K., Märte, M., Reiter, M., Schwenk-Zieger, S. and Harréus, U. (2011) The Impact of EGFR Stimulation and Inhibition on BPDE Induced DNA Fragmentation in Oral/Oropharyngeal Mucosa in Vitro. Oral Oncology, 47, 1141-1147. http://dx.doi.org/10.1016/j.oraloncology.2011.08.006

[65] Sun, Z., Sood, S., Li, N., Yang, P., Newman, R.A., Yang, C.S. and Chen, X. (2008) Chemoprevention of 7,12-Dimethylbenz[a]anthracene (DMBA)-Induced Oral Carcinogenesis in Hamster Cheek Pouch by Topical Application of a Dual Inhibitor of Epidermal Growth Factor Receptor (EGFR) and ErbB2 Tyrosine Kinases. Oral Oncology, 44, $652-$ 657. http://dx.doi.org/10.1016/j.oraloncology.2007.08.006

[66] Pogorzelski, M., Ting, S., Gauler, T.C., Breitenbuecher, F., Vossebein, I., Hoffarth, S., Markowetz, J., Lang, S., Bergmann, C., Brandau, S., Jawad, J.A., Schmid, K.W., Schuler, M. and Kasper, S. (2014) Impact of Human Papilloma Virus Infection on the Response of Head and Neck Cancers to Anti-Epidermal Growth Factor Receptor Antibody Therapy. Cell Death Disease, 5, e1091. http://dx.doi.org/10.1038/cddis.2014.62

[67] Mirghani, H., Amen, F., Moreau, F., Guigay, J., Hartl, D.M. and St Guily, J.L. (2014) Oropharyngeal Cancers: Relationship between Epidermal Growth Factor Receptor Alterations and Human Papillomavirus Status. European Journal of Cancer, 50, 1100-1111. http://dx.doi.org/10.1016/j.ejca.2013.12.018

[68] Surviladze, Z., Sterk, R.T., De Haro, S.A. and Ozbun, M.A. (2013) Cellular Entry of Human Papillomavirus Type 16 Involves Activation of the Phosphatidylinositol 3-Kinase/Akt/mTOR Pathway and Inhibition of Autophagy. Journal of Virology, 87, 2508-2517. http://dx.doi.org/10.1128/JVI.02319-12

[69] Woodworth, C.D., Diefendorf, L.P., Jette, D.F., Mohammed, A., Moses, M.A., Searleman, S.A., Stevens, D.A., Wilton, 
K.M. and Mondal, S. (2011) Inhibition of the Epidermal Growth Factor Receptor by Erlotinib Prevents Immortalization of Human Cervical Cells by Human Papillomavirus Type 16. Virology, 421, 19-27. http://dx.doi.org/10.1016/j.virol.2011.09.014

[70] Kwak, K., Jiang, R., Wang, J.W., Jagu, S., Kirnbauer, R. and Roden, R.B.S. (2014) Impact of Inhibitors and L2 Antibodies upon the Infectivity of Diverse Alpha and Beta Human Papillomavirus Types. PLoS ONE, 9, e97232. http://dx.doi.org/10.1371/journal.pone.0097232 
Scientific Research Publishing (SCIRP) is one of the largest Open Access journal publishers. It is currently publishing more than 200 open access, online, peer-reviewed journals covering a wide range of academic disciplines. SCIRP serves the worldwide academic communities and contributes to the progress and application of science with its publication.

Other selected journals from SCIRP are listed as below. Submit your manuscript to us via either submit@scirp.org or Online Submission Portal.
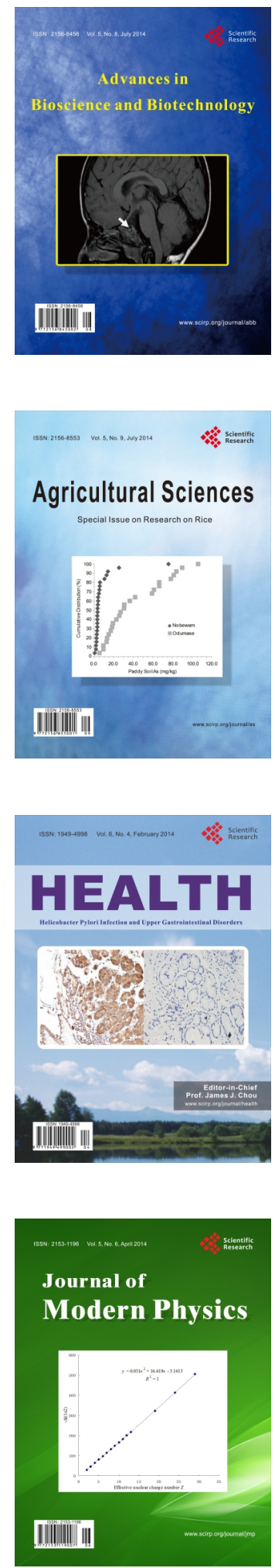
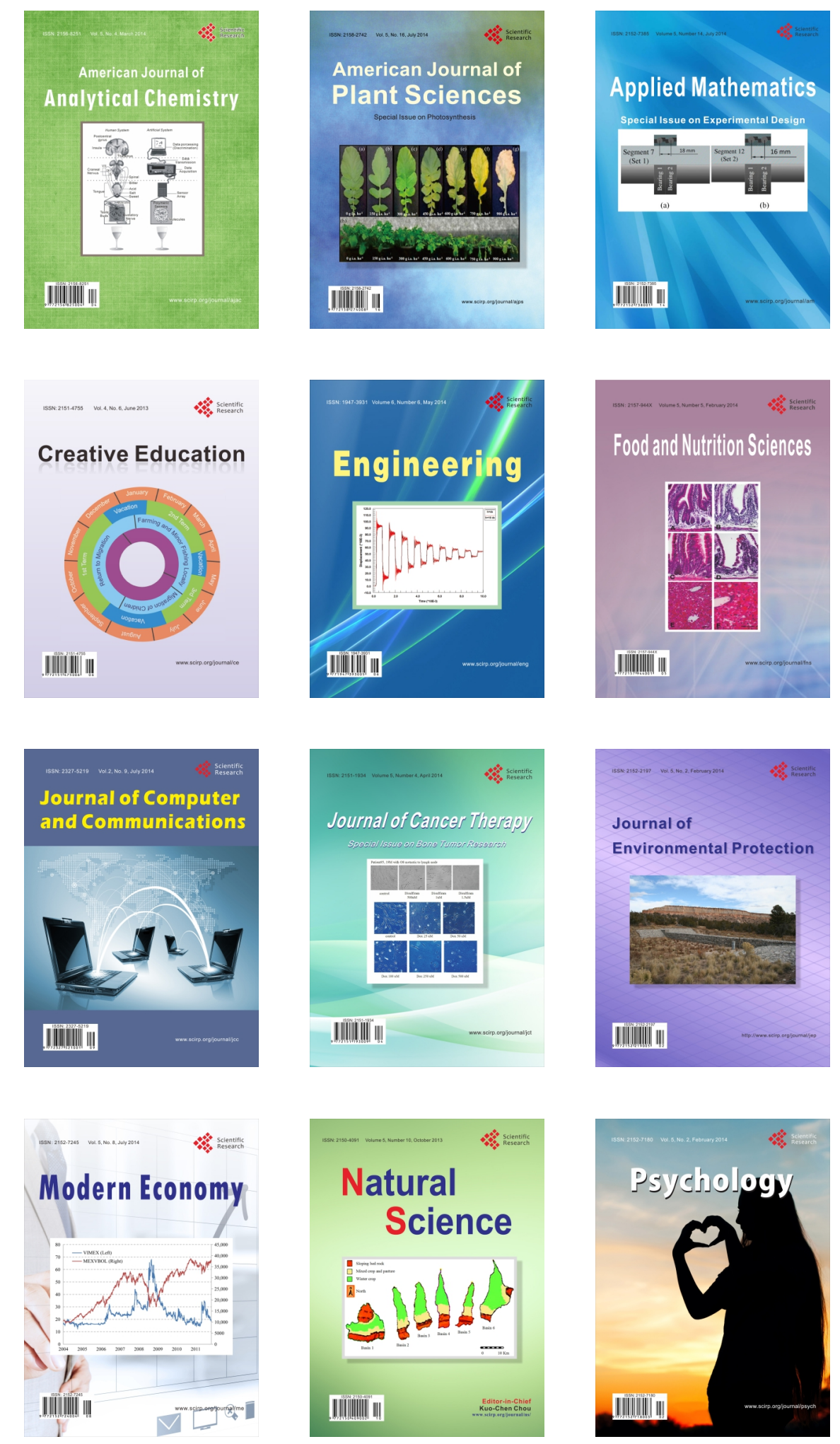